\title{
18. LATE NEOGENE PLANKTONIC FORAMINIFERS: EAST PACIFIC RISE AND GALAPAGOS SPREADING CENTER-DEEP SEA DRILLING PROJECT LEG 54
}

\author{
George W. Lynts, Department of Geology, Duke University, Durham, North Carolina
}

\begin{abstract}
On Deep Sea Drilling Project Leg 54, we recovered upper Pliocene (Globigerinoides obliquus: PL6 zone) to Pleistocene sediments from the equatorial East Pacific Rise (EPR) and Galapagos spreading center (GSC). Progressively older sediments were drilled at increasing distances from the crest, with the exception of the sediment drilled in the deepest trough known in the Siqueiros fracture zone. The anomalous age obtained at the latter site suggests that the basalt which was drilled may represent fracture zone volcanism. Paleoenvironmental analysis using the planktonic foraminifers at the EPR sites indicated the presence of environmental cycles of shorter wave length during the interval from 0 to $0.24 \mathrm{Ma}$, whereas cycles of longer wave length occurred from 0.43 to $2.17 \mathrm{Ma}$. The planktonic foraminiferal taphocoenoses at the EPR sites were strongly affected by selective dissolution which indicated that these EPR sites have been near either the lysocline or carbonate compensation surface since the upper Pliocene. The planktonic foraminiferal thanatocoenoses at the GSC sites were preserved better than those at the EPR sites. The number of planktonic foraminiferal species generally was greatly reduced in the green mud associated with the GSC hydrothermal mounds. More species were found in older than in younger green mud; this suggests that there probably was an increase in the rate of production of green mud sometime after the initiation of the hydrothermal system.
\end{abstract}

\section{INTRODUCTION}

On Deep Sea Drilling Project Leg 54, we recovered upper Pliocene to Pleistocene sediments from the equatorial East Pacific Rise (EPR) and the Galapagos spreading center (GSC) (Figures 1, 2, 3, and 4). Sediments from the EPR region were primarily foraminiferal-nannofossil ooze, with the exception of Site 423 where mainly nannofossil ooze was recovered (Figure 3). Sites 424 and 425 were drilled in the vicinity of the GSC (Figure 2). Site 424 was drilled about $22 \mathrm{~km}$ south of the GSC in the region of hydrothermal mounds (Hekinian et al., 1978; Corliss et al., 1979; Natland et al., 1979), and the sediments consisted of green, clay-rich muds that were interbedded with and underlain by foraminiferal-nannofossil ooze (Figure 4). From Site 425, which was drilled about $62 \mathrm{~km}$ north of the GSC, we recovered primarily foraminiferal-nannofossil ooze (Figure 4). With the exception of within the green, clay-rich mud, the planktonic foraminifers were preserved better in the vicinity of the GSC than they were near the EPR.

The Leg 54 sites lie beneath the equatorial Pacific water mass (Sverdrup et al., 1942; Bradshaw, 1959;
Reid, 1966). The EPR region lies beneath the North Equatorial Countercurrent, whereas the GSC sites lie near where the South Equatorial Current turns westward (Sverdrup et al., 1942; Bradshaw, 1959; Reid, 1966). Circulation in the vicinity of the GSC sites is complicated by numerous eddies, whose locations vary from year to year (Sverdrup et al., 1942). The GSC sites may occur in an area of high productivity because of equatorial divergence and upwelling (Sverdrup et al., 1942; Bradshaw, 1959).

Study of the plankton in the vicinity of Leg 54 sites indicated variable concentrations of planktonic foraminifers (Bradshaw, 1959). Large populations may be associated with the upwelling resulting from the spiral circulation of the North Equatorial Countercurrent (Sverdrup et al., 1942; Bradshaw, 1959; Reid, 1966). The planktonic foraminifers living in the vicinity of Leg 54 sites belong to the equatorial west central fauna of Bradshaw (1959). The equatorial west central fauna was characterized by Globoquadrina conglomerata (Schwager), Globorotalia tumida (Brady), Pulleniatina obliquiloculata (Parker and Jones), and 'Sphaeroidinella dehiscens (Parker and Jones),"' which were restricted to 


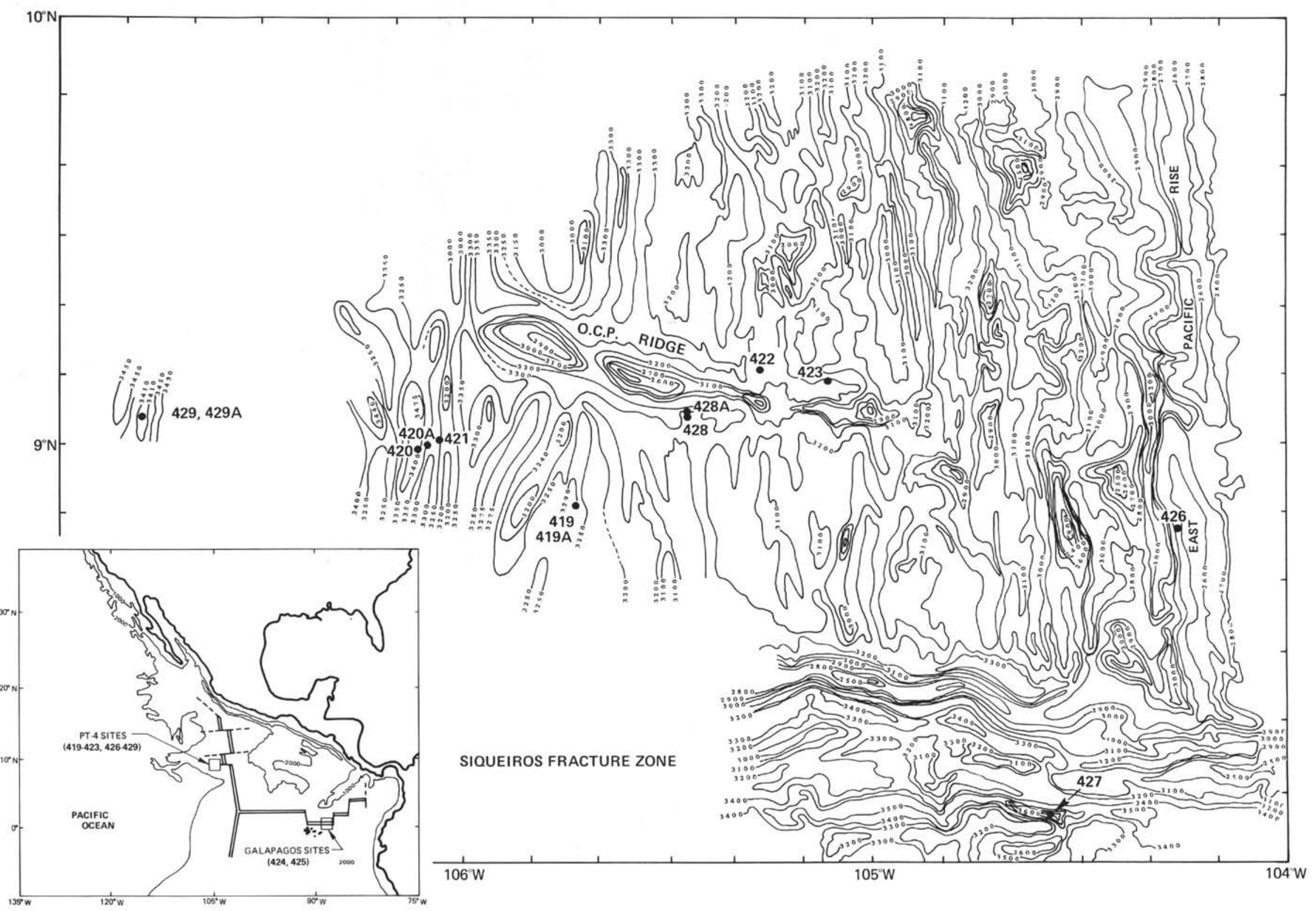

Figure 1. Leg 54 drill sites on the west flank of the EPR. Inset: Location of Leg 54 principal target areas in the eastern Pacific. 

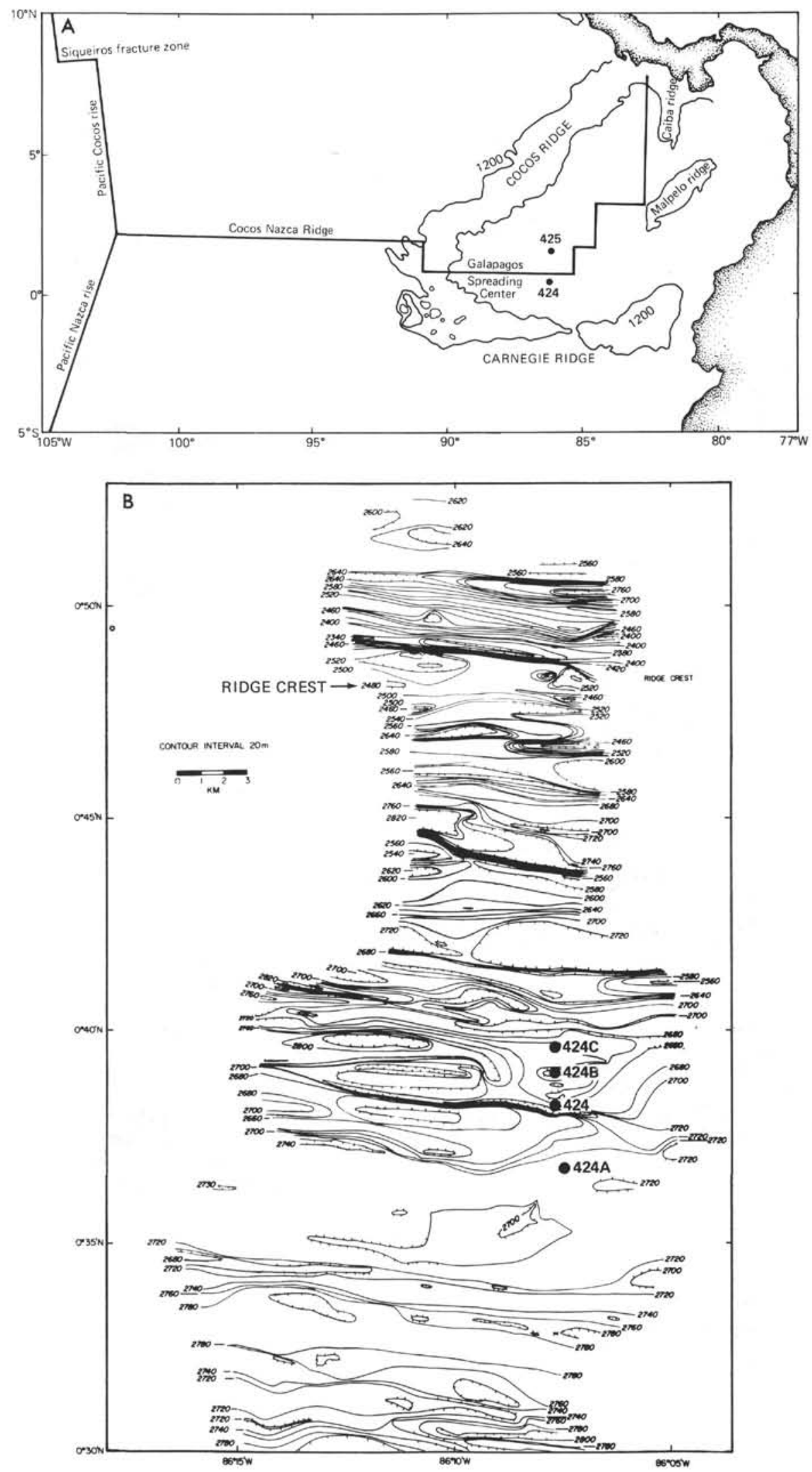

Figure 2. A. General bathymetric map of the eastern Pacific Ocean, showing Sites 424 and 425 from the GSC (Adapted from Hekinian et al., 1978.) B. Bathymetric map of the GSC and hydrothermal mounds field. Contour interval in corrected meters. The locations of Site 424 holes are shown. (From Hekinian et al., 1978.) 
A

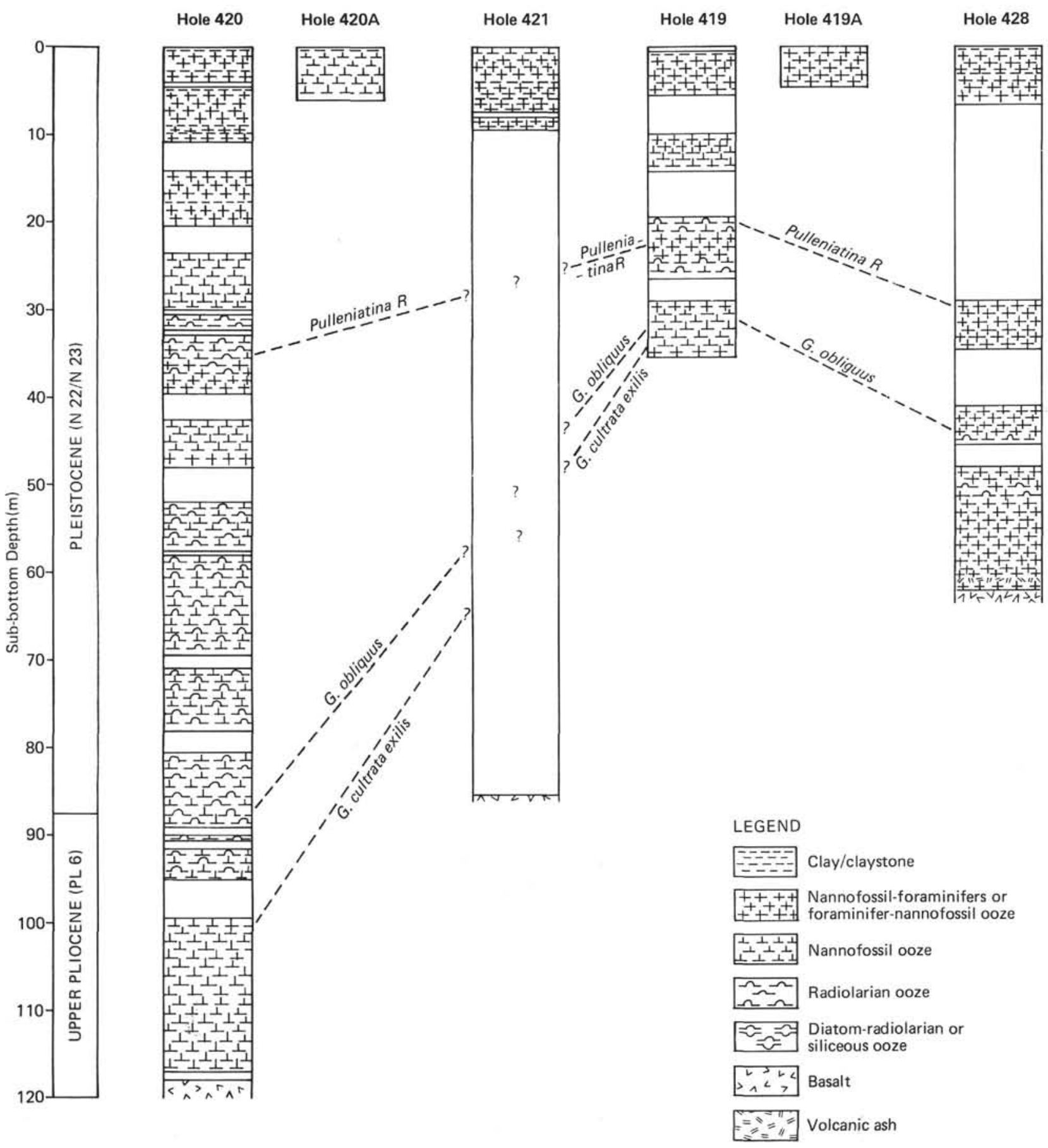

Figure 3. A. Correlation of Leg 54 EPR holes. B. Correlation of Leg 54 Siqueiros fracture zone Hole 427 and the number of species of planktonic foraminifers. 
B

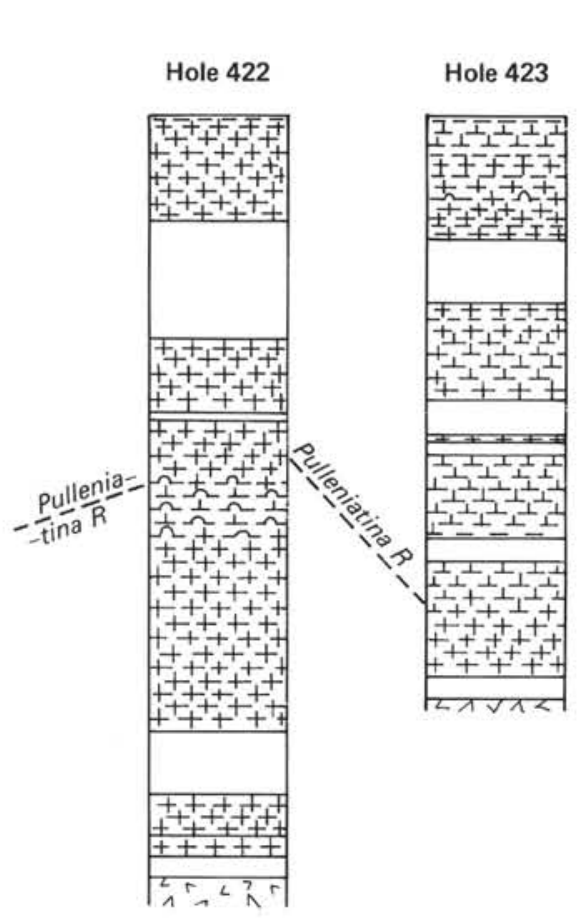

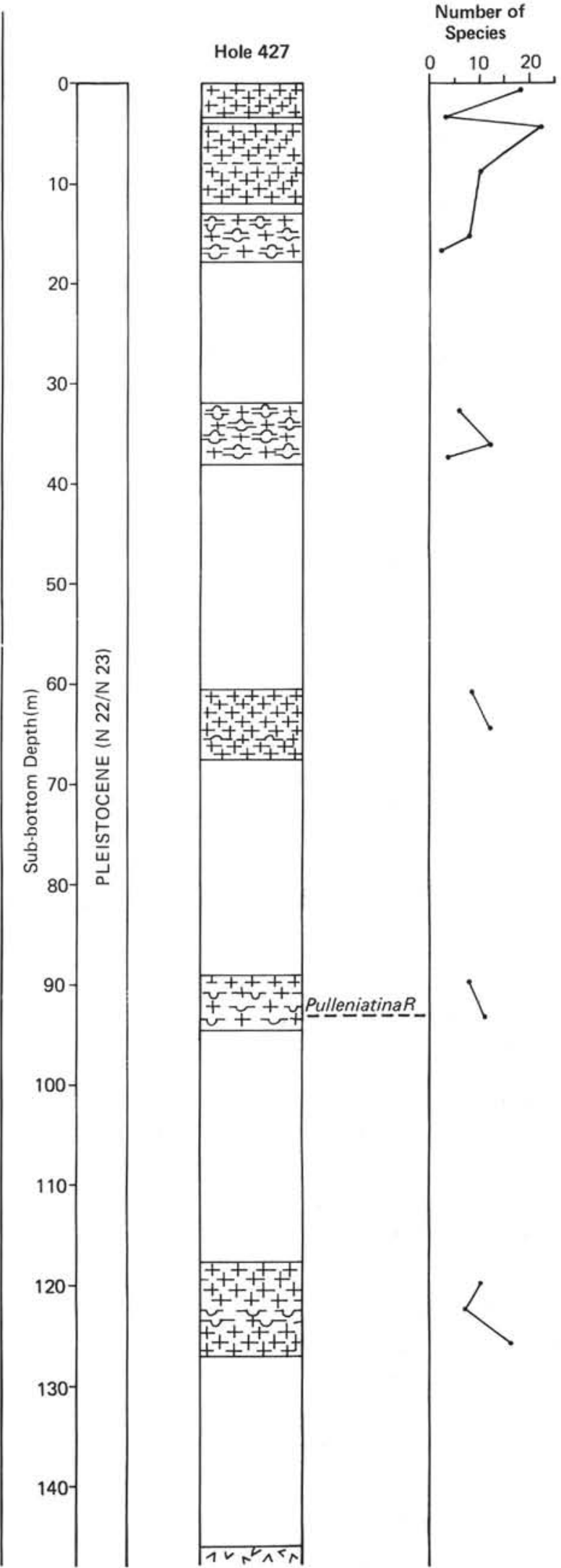

Figure 3. (Continued). 


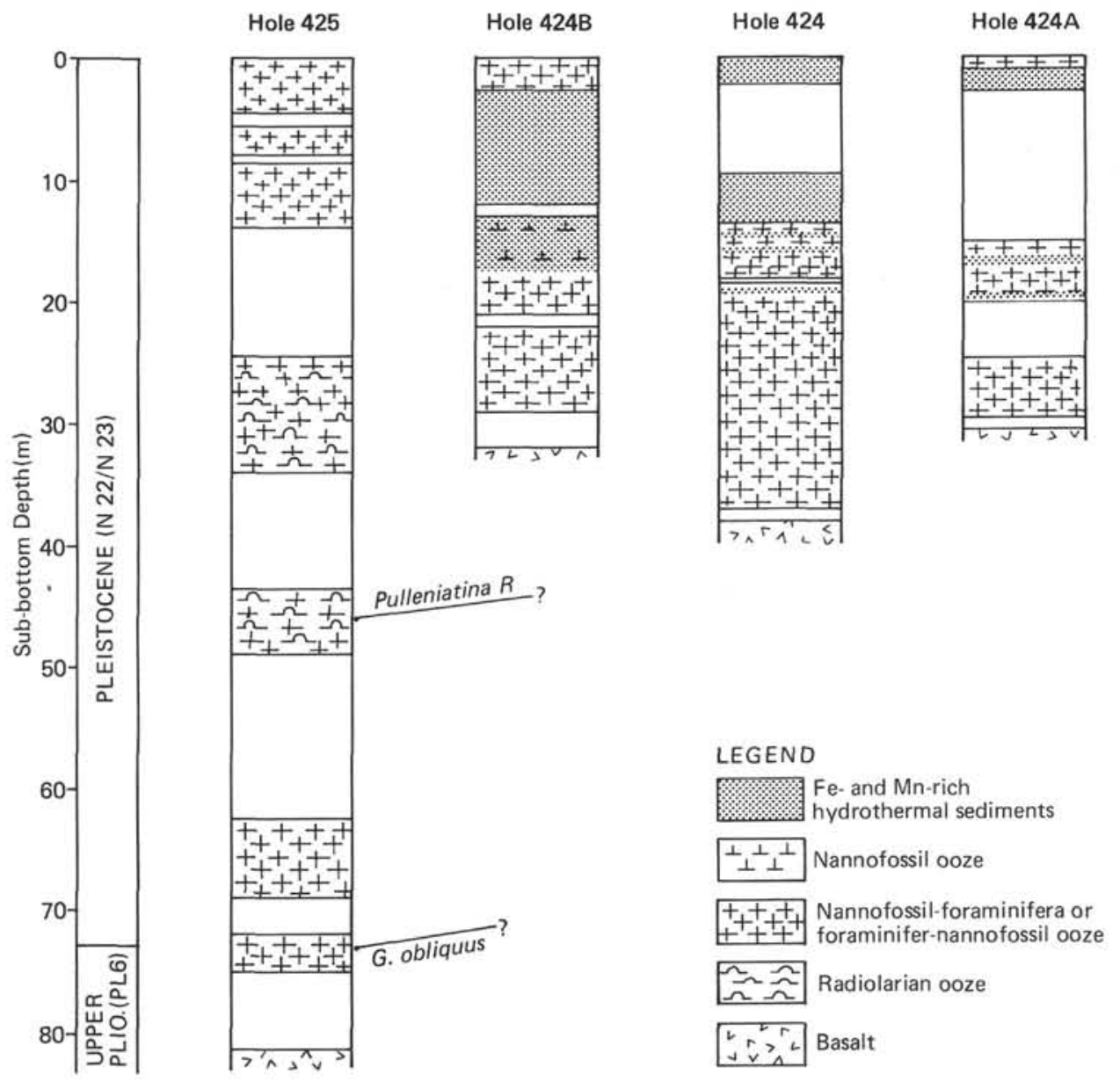

Figure 4. Correlation of Leg 54 GSC holes.

this fauna (Bradshaw, 1959). Bradshaw (1959) also indicated that Globorotaloides hexagona (Natland), Globigerinella siphonifera (d'Orbigny), Globigerinita glutinata (Egger), Globigerinoides conglobatus (Brady), Globigerinoides ruber (d'Orbigny), Globigerinoides sacculifer (Brady), Globorotalia hirsuta (d'Orbigny), Globorotalia cultrata (d'Orbigny), and Hastigerinella digitata (Rhumbler) were common species in the equatorial west central fauna. Analysis of the species distribution figures given in Bradshaw (1959) indicates Globigerinita glutinata, Globigerinoides sacculifer, Globigerinoides ruber, Globorotalia cultrata, and Hastigerinella digitata were more abundant in the plankton over the EPR sites than in the vicinity of the GSC sites, whereas Globorotalia hirsuta and Turborotalia (Neogloboquadrina) dutertrei (d'Orbigny) were more common over the GSC sites than the EPR sites.

Comparison of the foraminiferal populations in the plankton (Bradshaw, 1959) with planktonic foraminifers in surface sediments in the vicinity of Leg 54 sites (Parker and Berger, 1971; Bé, 1977) indicates the species compositions are fairly similar to one another. Generally the difference between the planktonic foraminiferal biocoenosis and thanatocoenosis represents a decrease in the relative abundance of the dissolution-liable spe- cies (Parker and Berger, 1971) Globigerinoides ruber, Globigerinella siphonifera, Globigerinoides sacculifer, and Globigerinoides conglobatus. The decrease in relative abundance of the more dissolution-resistant species (Parker and Berger, 1971) "Orbulina universa d'Orbigny," Globorotalia hirsuta, and Globorotalia cultrata (in the vicinity of the EPR sites) is more difficult to explain. Factors other than selective dissolution that may influence planktonic foraminiferal thanathocoenoses are: (1) ingestion by scavengers, (2) settling rates and current transport, (3) scouring and redeposition, and (4) longterm productivity (Bé, 1977).

\section{METHODS}

The 211 samples that were analyzed consisted mainly of unconsolidated sediments. The samples were selected randomly for washing through a 200 -mesh $(74-\mu \mathrm{m})$ sieve, and the retained residue was dried in a $95^{\circ} \mathrm{C}$ oven. All of the planktonic foraminifers in each sample were identified to develop an accurate record of the species and subspecies occurring in the samples. No attempt was made to determine the relative abundance of the species and subspecies in most samples. However, the coiling direction of all individuals of Pulleniatina was determined, because Hays et al. (1969), Saito et al. (1975), and Saito 
(1976) found that changes in coiling direction of Pulleniatina were useful in correlating late Neogene sediments in the equatorial Pacific.

Orr and Jenkins (1977) and Jenkins and Orr (1972) characterized the dissolution of planktonic foraminifers collected on Leg 9, eastern equatorial Pacific, with the use of a number of species. Within thanatocoenoses, species richness is the result of factors intrinsic to the biocoenoses (Hutchinson, 1961; Lipps, 1970; Connell, 1978) and factors that affect the organisms after death (Bé, 1977). To test the accuracy with which species richness estimates planktonic foraminiferal dissolution, the relative abundance of planktonic foraminiferal species in 27 samples from Site 420 (EPR) was determined. These data were then used to calculate the dissolution index of Berger (1970) for each of these samples. The relationship between number of species and the Berger dissolution index was tested, using the Spearman coefficient of rank correlation (Steel and Torrie, 1960). The relationship was statistically significant $\left(r_{s}=-0.32, P\right.$ $=0.95$ ) but not particularly strong. The number of species was, therefore, only used as a gross estimator of planktonic foraminiferal dissolution in Leg 54 samples (Figures 3B, 5, and 6).

\section{PLANKTONIC FORAMINIFERAL ZONATION AND THE PLIOCENE/PLEISTOCENE BOUNDARY}

Hays et al. (1969), Jenkins and Orr (1972), Orr and Jenkins (1977), Kaneps (1973), Saito et al. (1975), and Quilty (1976) have studied the Late Neogene planktonic foraminiferal biostratigraphy of the eastern equatorial Pacific using piston cores and DSDP (Legs 9 and 16) cores. Hays et al. (1969) and Saito et al. (1975) related the planktonic foraminiferal biostratigraphy to magnetostratigraphy in the piston cores into a biochronology. Both Jenkins and Orr (1972) and Kaneps (1973) developed their own planktonic foraminiferal zonation for the late Neogene because they did not recognize the tropical/subtropical planktonic foraminiferal zonations of Banner and Blow (1965) and Blow (1969) at their DSDP sites, primarily because of the selective dissolution problem. The late Neogene zonation developed by Jenkins and Orr (1972) was based mainly on solution-resistant species (Stainforth et al., 1975), whereas the late Neogene zonation used by Kaneps (1973) was a combination of zones from Bolli (1966), Blow (1969), and Jenkins and Orr (1972). Quilty (1976) used the zonation of Blow (1969) for DSDP sites on the Nazca plate. Late Neogene planktonic foraminifers were strongly affected by dissolution (Quilty, 1976).

Hays et al. (1969), Berggren (1973), and Saito et al. (1975) recognized 14 planktonic foraminiferal datum events in the late Neogene. Datum I: A marked downward increase in the abundance of "Sphaeroidinella dehiscens" at the Brunhes/Matuyama boundary. Datum II: First appearance datum (FAD) of Pulleniatina obliquiloculata finalis Banner and Blow midway between the Jaramillo and Olduvai Events. Datum III: Last appearance datum (LAD) of Globigerinoides quadrilobatus fistulosus (Schubert) near the top of the Olduvai Event. Datum IV: FAD of Truncorotalia truncatuli- noides (d'Orbigny) near the base of the Olduvai Event. Datum V: LAD of all species of "Sphaeroidinellopsis," coincident with an upward increase in abundance of "Sphaeroidinella dehiscens," at the top of the Mammoth Event. Datum VI: LAD of Globorotalia margaritae Bolli and Bermudez at the Gauss/Gilbert boundary. Datum VII: Sharp left to right coiling change in Pulleniatina, primarily Pulleniatina primalis Banner and Blow, just above the Chociti (Gilbert a) Event. Datum VIII: LAD of “'Globigerina” nepenthes (Todd) at the top of the Chociti Event. Datum IX: FAD of Pulleniatina spectablis Parker near the top of the Gilbert $\mathrm{c}_{1}$ event. Datum X: FAD of "Sphaeroidinella dehiscens" midway between the Gilbert $c_{2}$ event and the Epoch 5 boundary. Datum XI: FAD of Globorotalia tumida above the Epoch 5 boundary. Datum XII: LAD of Globoquadrina dehiscens (Chapman, Parr, and Collins) just above the Epoch 5 boundary. Datum XIII: FAD of Globorotalia margaritae during Epoch 5 event a. Datum XIV: FAD of Pulleniatina primalis during the early part of Epoch 5.

Hays and Shackleton (1976) and Berggren and Van Couvering (1978) argue that FADs and LADs represent geologically instantaneous events. Dispersal of planktonic organisms is dependent upon average drift rates of surface currents and geographic and seasonal factors that limit a species biogeographic distribution (Weyl, 1978). Average drift rates of major surface currents suggest that species populations will become distributed throughout their adaptive ranges in geologically very short time intervals within an ocean basin. Dispersal between ocean basins would probably take longer, but still represent geologically short time intervals. Dispersal rates combined with the resolving power of geochronologic systems result in biostratigraphic datum events that are geologically instantaneous (Berggren and Van Couvering, 1978). Berggren and Van Couvering (1978) consider that the random variation found in the position of biostratigraphic datum events is the result of stratigraphic and methodologic noise.

LaBrecque et al. (1977) revised the Cenozoic magnetostratigraphic time scale. The main change in the magnetochronology was in magnetochrons prior to $2 \mathrm{~A}$ (base of Gauss Epoch), which was assumed to be $3.32 \mathrm{Ma}$. The biochronology of the late Neogene planktonic foraminiferal datum events of Hays et al. (1969), Berggren (1973), and Saito et al. (1975) have been recalibrated using the revised magnetochronology of LaBrecque et al. (1977) in Table 1.

Berggren (1973) has revised the planktonic foraminiferal zonation of the Pliocene. He recognized six partial range zones in the Pliocene: Zone PL1: "Globigerina" nepenthes-Globorotalia tumida ( $\sim 4.9$ to $3.76 \mathrm{Ma})$; Zone PL2: Globorotalia margaritae-Globorotalia hirsuta praehirsuta Blow (3.76 to $3.32 \mathrm{Ma}$ ); Zone PL3: "Sphaeroidinellopsis subdehiscens (Blow)"-Globoquadrina altispira (Cushman and Jarvis) (3.32 to 3.0 Ma); Zone PL4: Globoquadrina altispira-Globorotalia multicamerata Cushman and Jarvis (3.0 to $\sim 2.86 \mathrm{Ma})$; Zone PL5: Globorotalia miocenica Palmer-Globorotalia cultrata exilis Blow ( $\sim 2.86$ to $\sim 2.2 \mathrm{Ma}$ ); and Zone 


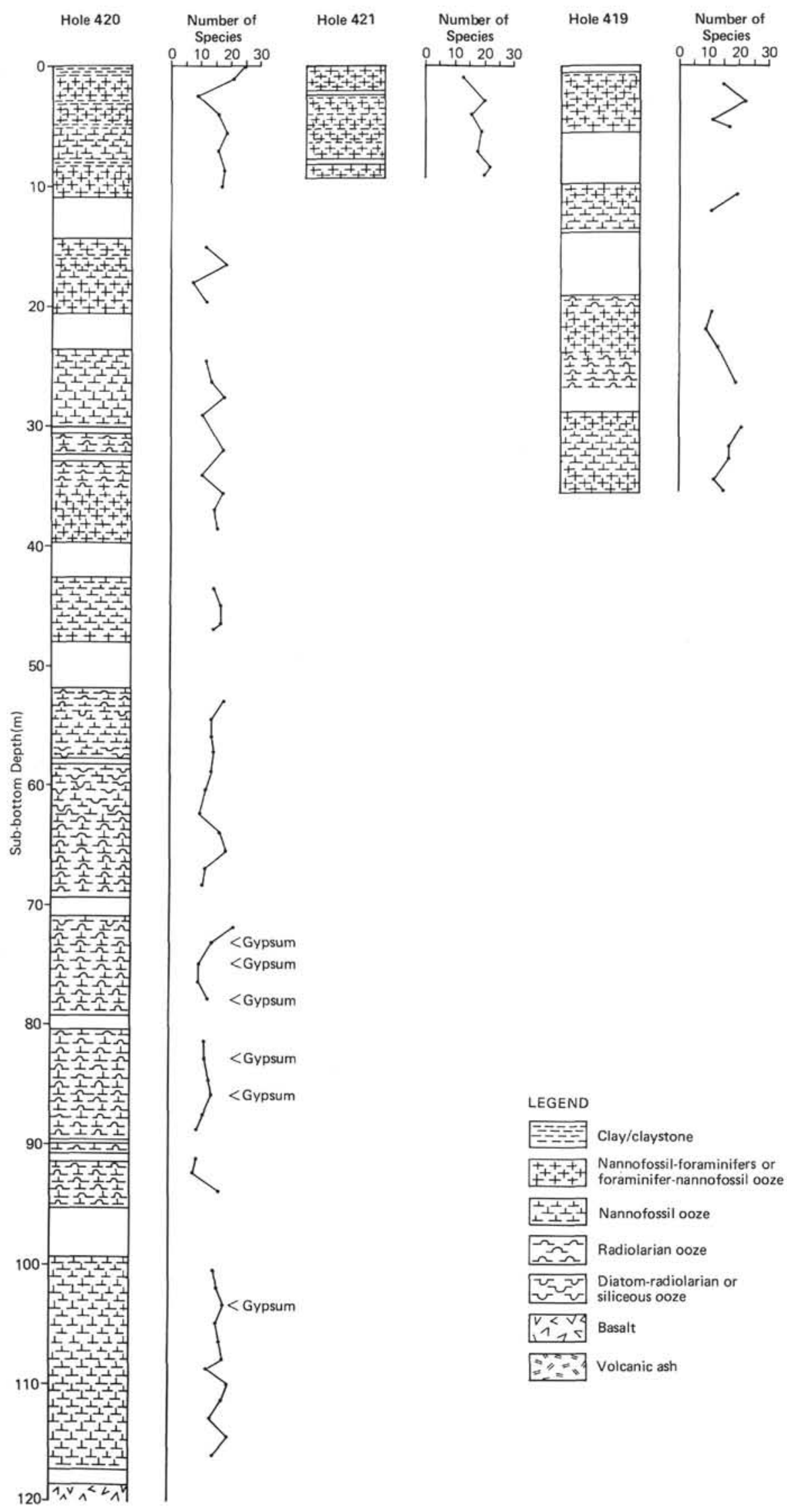

Figure 5. Number of species of planktonic foraminifers at Leg 54 EPR sites. Location of autochthonous gypsum crystals are indicated at Site 420. 


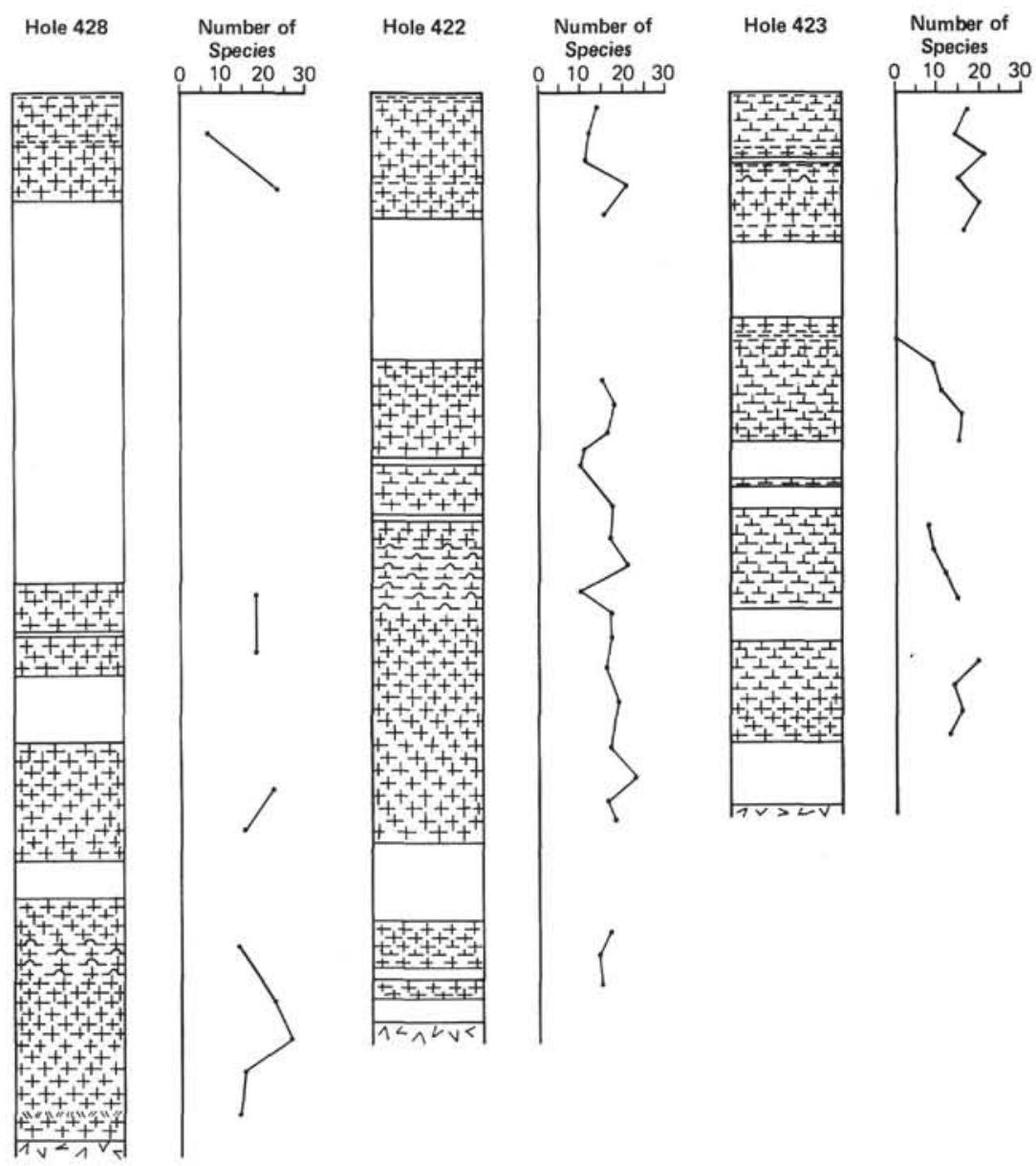

Figure 5. (Continued). 


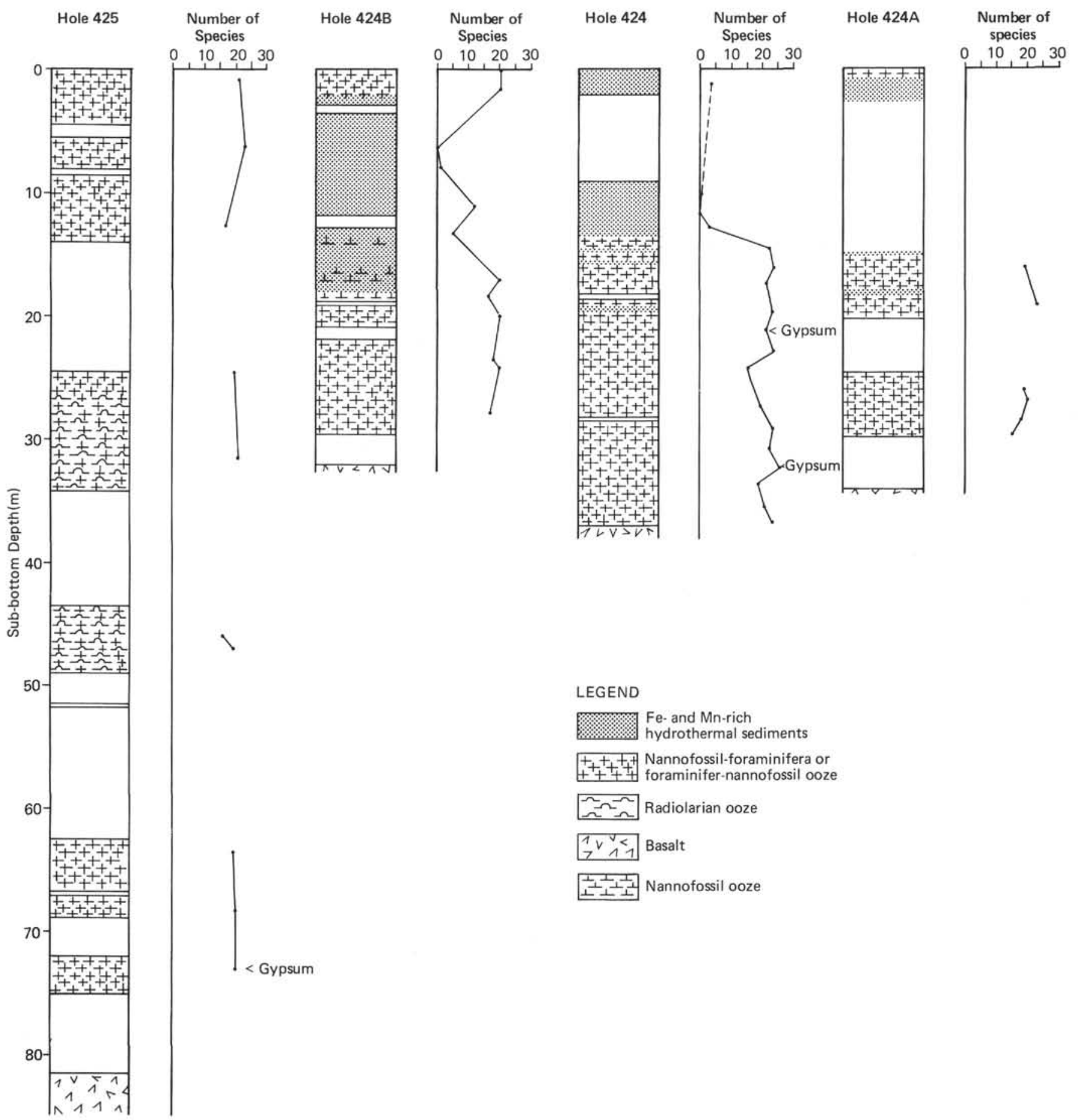

Figure 6. Number of species of planktonic foraminifers at Leg 54 GSC sites. Location of autochthonous gypsum crystals are indicated at Holes 424 and 425.

PL6: Globigerinoides obliquus Bolli ( 2.2 to $1.62 \mathrm{Ma})$. The top of the Globigerinoides obliquus (PL6) zone was placed at the LAD of Globigerinoides obliquus extremus Bolli and Bermudez that was considered to occur near the base of the Olduvai Event $(\sim 1.8 \mathrm{Ma})$, which was considered to be the Pliocene/Pleistocene boundary (Berggren, 1973).

The LAD of Globigerinoides obliquus extremus occurs at approximately the same level as the FAD of
Truncorotalia truncatulinoides, which defines the base of the Truncorotalia truncatulinoides (N22) zone (Banner and Blow, 1965; Blow, 1969), that was considered to be the lowest planktonic foraminiferal zone of the Pleistocene (Blow, 1969; Berggren, 1973). Berggren (1973) placed the Pliocene/Pleistocene boundary at the boundary of the Globigerinoides obliquus (PL6) and Truncorotalia truncatulinoides (N22) zones, which he considered to occur at about $1.8 \mathrm{Ma}$. 
TABLE 1

Biochronology of late Neogene Planktonic Foraminiferal Datum Events (Hays et al., 1969; Berggren, 1973; Saito et al., 1975), Using Revised Magnetochrons of LaBrecque et al. (1977)

\begin{tabular}{ccc}
\hline Datum Level & Type & Age (Ma) \\
\hline I "Sphaeroidinella dehiscens" & Upward decrease in abundance & 0.7 \\
II Pulleniatina obliquiloculata finalis & FAD & $\sim 1.3$ \\
III Globigerinoides quadrilobatus fistulosus & LAD & $\sim 1.6$ \\
IV Truncorotaila truncatulinoides & FAD & $\sim 1.8$ \\
V "Sphaeroidinellopsis" spp. & LAD & 3.0 \\
VI Globorotalia margaritae & LAD & 3.32 \\
VII Pulleniatina (primarily P, primalis) & Left to right coiling change & $\sim 3.7$ \\
VIII "Globigerina" nepenthes & LAD & 3.76 \\
IX Pulleniatina spectablis & FAD & $\sim 4.24$ \\
X "Sphaerodinella dehiscens" & FAD & $\sim 4.8$ \\
XI Globorotalia tumida & FAD & $\sim 4.9$ \\
XII Globoquadrina dehiscens & LAD & $\sim 5.0$ \\
XIII Globorotalia margaritae & FAD & $\sim 5.36$ \\
XIV Pulleniatina primalis & FAD & $\sim 5.6$ \\
\hline
\end{tabular}

aFAD $=$ first appearance datum

${ }^{b} \mathrm{LAD}=$ last appearance datum.

Haq et al. (1977) have since revised the age of the Pliocene/Pleistocene boundary. They indicated that the LAD of Globigerinoides obliquus was coincident with the marker bed (Pliocene/Pleistocene boundary within the Calabrian stratotype) at Le Castella and with the top of the Olduvai Event in piston cores (V16-205 and V12-18) from the subtropical Atlantic Ocean. Using the revised magnetochronology of LaBrecque et al. (1977), the age of the Pliocene/Pleistocene boundary would be about $1.62 \mathrm{Ma}$. The FAD of Truncorotalia truncatulinoides within the Calabrian stratotype at La Castella is probably unreliable (Haq et al., 1977) because of the rarity of specimens (Bayliss, 1969, 1975). The FAD of Truncorotalia truncatulinoides in piston cores is associated with the lower boundary of the Olduvai Event (Hays et al., 1969; Haq et al., 1977) and has an age of approximately 1.83 Ma (LaBrecque et al., 1977). The revised age for the Pliocene/Pleistocene boundary leaves a partial overlap of the Globigerinoides obliquus (PL6) and Truncorotalia truncatulinoides (N22) zones of about the duration of the Olduvai Event. Therefore, the N22: Truncorotalia truncatulinoides partial range zone (Banner and Blow, 1965; Blow, 1969) is emended to an interval zone between the LAD of Globigerinoides obliquus extremus $(1.62 \mathrm{Ma})$ and the first occurrence of the N22: Globigerina calida-"Sphaeroidinella dehiscens excavatus" Banner and Blow assemblage zone, which Berggren (1973) places at about the Brunhes/Matuyama boundary $(0.7 \mathrm{Ma})$.

The late Neogene planktonic foraminiferal zonation used in this report is a combination of the emended zonation of Banner and Blow (1965) and Blow (1969) for the Pleistocene and the zonation of Berggren (1973) for the Pliocene. The Pliocene/Pleistocene boundary is placed at about 1.62 Ma (top of the Olduvai Event) following the revision given by Haq et al. (1977).

\section{EPR}

\section{Introduction}

Planktonic foraminifers were analyzed at Sites 419 , $420,421,422,423$, and 428 on the west flank of the
EPR and at Site 427, which was drilled in the deepest known trough in the Siqueiros fracture zone (SFZ) (Figure 1 ). Sites 419,420 , and 422 were continuously cored with 62 per cent, 74 per cent, and 76 per cent sediment recovery, respectively (Figure 3). Drilling at Site 419 did not attempt basalt basement penetration. As would be expected, progressively older sediments were drilled with increasing distance from the EPR crest (Figure 3). Sites nearest the crest (Sites 423 and 422) encountered lower Pleistocene sediments, whereas Sites 428, 419, and 420 penetrated the Pliocene/Pleistocene boundary ( 1.6 Ma) into the upper Pliocene (zone PL6: Globigerinoides obliquus).

A chronology was developed from EPR Sites 419, $420,422,423$, and 428 , SFZ Site 427 , and GSC Site 425 using the planktonic foraminiferal and diatom (Barron, this volume) datum events. The chronology of samples between datum planes was interpolated with the use of linear sedimentation rates estimated from the datum events. Table 2 presents the estimated age of the oldest sediment drilled at the above sites.

Extrapolating the estimated age for the oldest sediment drilled at Site 427 in the SFZ (Table 2), one obtains the minimum age of the basalt drilled $(1.15 \mathrm{Ma})$ and this age is found to be anomalous in relationship to the distance of the site from the EPR crest given the rates of accretion for this portion of the ridge system. This suggests that the basalt drilled in the SFZ may represent fracture zone volcanism.

\section{Dissolution}

The majority of the samples analyzed from the EPR sites were affected by selective dissolution as evidenced by fragmented tests. No planktonic foraminifers were found at $100 \mathrm{~cm}$ in Section 423-3-1 (Figure 5). This site may have been below the carbonate compensation surface (CCS) at time of deposition of these sediments (at about $345 \mathrm{ka})$.

Berger (1970) indicated that the lysocline may slope from 3000 to 3250 meters in an east to west direction in the vicinity of the EPR sites. The corrected depths of the EPR sites range in depth from 3161 to 3381 meters with increasing distance from the ridge crest (east to west direction); depth of the SFZ site was 3824 meters. The up-

TABLE 2

Estimated age of oldest sediment drilled at Leg 54 sites.

\begin{tabular}{ccl}
\hline Site & $\begin{array}{c}\text { Estimated Age } \\
(\mathrm{Ma})\end{array}$ & \\
\hline 423 & 0.95 & Nearest EPR crest \\
422 & $1.4(1.1)^{\mathrm{a}}$ & \\
428 & 2.0 & \\
$(419)$ & $(1.95)^{\mathrm{b}}$ & \\
420 & 2.2 & Farthest from EPR crest \\
427 & 1.0 & Siqueiros fracture zone \\
425 & 1.7 & Galapagos spreading center \\
\hline
\end{tabular}

aThis site has an age of about $1.4 \mathrm{Ma}$ if the basalt drilled in Core 422-7 was a sill; if basalt in Core 422-7 was basement, the age would be about 1.1 Ma.

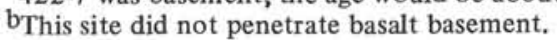


permost sample at Site 420 was very well preserved (Figure 5), indicating that the lysocline presently may be deeper than 3381 meters in this region. The EPR sites may be either near or beneath the lysocline.

Over an interval of $2 \mathrm{Ma}$ the thermal contraction model for fast-spreading ridges, such as the EPR, suggests that a point originating on the ridge crest would move down-slope between 200 and 400 meters (Sclater et al., 1971; Le Pichon et al., 1973; Berger and Winterer, 1974). If the lysocline has remained at approximately the same depth for the past $2 \mathrm{Ma}$, the EPR sites have probably impinged upon the lysocline as they moved down-slope. This would be expected to result in the planktonic foraminifers being better preserved at sites nearest the ridge crest and becoming progressively less well preserved at sites farther removed from the ridge crest. Also, one might expect a trend within the sediment drilled at each site of the planktonic foraminifers of being better preserved in older sediments, deposited near the ridge crest, and becoming less well preserved in younger sediments.

No consistent relationship is found between mean number of planktonic foraminifers at EPR sites and distance of the sites from the ridge crest. No linear trend of increasing number of species with depth in sediment is apparent at the EPR sites (Figure 5), but Miller and Kahn (1962) indicate that conclusions about time series should not be drawn from visual inspection. Spearman's coefficient of rank correlation may be used to determine if a linear trend occurs in a series (Miller and Kahn, 1962). No statistically significant linear trends occur in the number of species with depth in sediment at the EPR sites.

This suggests that the lysocline may not have maintained a constant depth over the past $2 \mathrm{Ma}$. Fluctuation in the lysocline and CCS during the Pleistocene, and probably upper Pliocene, has been related to climatic fluctuations (Hays et al., 1969; Berger and Winterer, 1974). Berger and Winterer (1974) suggested that in tropical waters increased dissolution of carbonate occurs in a "warm ocean", whereas a "cold ocean" results in decreased carbonate dissolution. The fluctuation in number of planktonic foraminiferal species at the EPR sites was analyzed to see if the time series differs significantly from random (Miller and Kahn, 1962). Only at Sites 420 and 423 (Figure 5) did the time series differ from what would be expected from random fluctuation. Hays et al. (1969) were able to correlate a series of carbonate maxima and minima in piston cores from the eastern equatorial Pacific. It was not possible to correlate the fluctuations in number of planktonic foraminiferal species at Sites 420 and 423 because of the incomplete recovery of sediment.

In several of the Site 420 samples for which the Berger (1970) dissolution index was calculated, there appeared to be a discrepancy between the dissolution indices and number of species and number of planktonic foraminifers in the samples. Most of these samples also contained evidence of dissolution in the form of many fragmented tests. The discrepancy was that the dissolution index indicated lack of much dissolution, whereas all other lines of evidence-number of species, number of specimens and fragmented tests-suggested significant dissolution. In these samples the taphocoenoses were dominated by the relative abundance of the more dissolution-liable species Globigerinoides ruber and Globigerinita glutinata (Table 3). In some of these samples, the fragments were primarily the keels of dissolution-resistant species. The relatively high abundance in these taphocoenoses of dissolution-liable species may be the result of their relatively high productivity in tropical waters (Bradshaw, 1959; Bé, 1977). This might result in more dissolution-liable species being preserved in the taphocoenoses than dissolution-resistant species which have lower relative productivities, and consequently a biased dissolution index.

Finally, in the lower Pleistocene and upper Pliocene sediments at Site 420 , autochthonous gypsum crystals were found (Figure 5). Most samples containing gypsum contain fewer than the average number of planktonic foraminiferal species for the site. One gypsum crystal had grown around a test of Globigerinoides ruber. Examination of SEM micrographs of this crystal did not indicate any dissolution of the test. Therefore, it does not appear that the growth of gypsum was related to the dissolution that affected these taphocoenoses.

\section{Paleoceanography}

The EPR sites presently underlie the North Equatorial Countercurrent (Sverdrup et al., 1942; Bradshaw, 1959; Reid, 1966) that supports an equatorial west central fauna (Bradshaw, 1959). All of the samples analyzed from the EPR sites contained species characteristic of the equatorial west central fauna.

Some of the EPR samples do contain species that normally characterize higher-latitude planktonic foraminiferal faunas. Dextral Turborotalia (Neogloboquadrina) pachyderma (Ehrenberg) and Globigerina bulloides d'Orbigny are more characteristic of subpolar faunas, whereas Truncorotalia inflata (d'Orbigny) characterizes the transitional fauna that occurs between the

TABLE 3

Solution Ranking of Planktonic Foraminifers (From Parker and Berger, 1971)

\begin{tabular}{ll}
\hline 1. Hastigerina pelagica & 19. Globigerina falconensis \\
2. Globorotalia anfracta & 20. Candeina nitida \\
3. Globigerinoides ruber & 21 . "Orbulina universa" \\
4. Globigerina rubescens & 22. Globorotalia scitula \\
5. Globigerinoides tenellus & 23. Globoquadrina hexagona \\
6. Globigerinella siphonifera & 24. Globigerina digitata \\
7. Globigerinella adamsi & 25. Globoquadrina conglomerata \\
8. Globigerinoides sacculifer & 26. Globorotalia hirsuta \\
9. Globigerinoides conglobatus & 27. Globorotalia truncatulinoides \\
10. Globigerina quinqueloba & 28. Globorotalia inflata \\
11. Globigerina bulloides & 29. Globorotalia crassaformis \\
12. Globigerina calida & 30. Globorotalia cultrata \\
13. Globorotalia fimbriata & 31. Globoquadrina dutertrei \\
14. Globigerinita uvula & 32. Globigerina pachyderma \\
15. Globigerinita glutinata & 33. "Globorotalia" pumilio \\
16. Globigerinita iota & 34. Pulleniatina obliquiloculata \\
17. Globorotalia sp. A. & 35. Sphaeroidinella dehiscens \\
18. Globorotalia sp. B. & 36. Globorotalia tumida \\
&
\end{tabular}


subpolar and subtropical faunas (Bé, 1977). Globigerina bulloides does occur at low latitudes, where it is commonly associated with boundary currents and areas of upwelling (Bé, 1977).

Figure $7 \mathrm{~A}$ is a histogram illustrating the number of occurrences of Neogloboquadrina pachyderma, Globigerina bulloides, and Truncorotalia inflata per 10-ka intervals of time at the EPR. These "cold-water" species occur in the time intervals: (1) 0 to $0.4 \mathrm{Ma}$, (2) 0.6 to 0.7 $\mathrm{Ma}$, (3) 0.8 to $1.2 \mathrm{Ma}$, and (4) 1.5 to $1.9 \mathrm{Ma}$, with highest occurrences during the intervals from 0 to $0.1 \mathrm{Ma}$ and 1.1 to $1.2 \mathrm{Ma}$. These intervals may represent periods of intensified upwelling and/or cooler water. Both intensified upwelling and cooler water might be the result of climatic fluctuations associated with continental glaciation.

In order to investigate the environmental fluctuations further, the mean diameter of all "Orbulina universa" tests in the samples from the EPR sites were measured, and Bé et al. (1973) found that this value was directly related to surface-water temperature (inversely related to latitude) in both plankton and sediment samples. Using the chronology developed at each EPR site, the mean test diameters were ordered into time series. Bé et al. (1973) also found an inverse relationship between mean test diameter and water depth in sediment samples. This suggests that a direct relationship might occur between test diameter and age of the sample, because of the thermal contraction model for oceanic ridges. Spearman's rank correlation coefficient was used to test for trends in the time series at each EPR site, and no statistically significant trends were found.

The time series at each EPR site was incomplete because of core recovery failures, discontinuous coring, and "Orbulina universa" not occurring in all samples. Therefore, the data from all EPR sites were combined into a single time series for the EPR (Table 4). A threepoint moving average (Miller and Kahn, 1962) was used to construct the time series (Figure 7B), because mean test diameter could not be estimated in those samples (17) that contained a single individual. Moving averages were calculated separately for the time intervals from 0 to $0.24 \mathrm{Ma}$ and 0.43 to $2.17 \mathrm{Ma}$, because of an hiatus in the occurrence of "Orbulina universa" at the EPR sites between 0.24 and $0.43 \mathrm{Ma}$ (Figure 7B). A null hypothesis that the fluctuations in mean test diameter were random was tested (Miller and Kahn, 1962) and rejected for each part of the time series $(0-0.24 \mathrm{Ma} ; K=-2.00$; $0.43-2.17$ Ma: $K=-4.81$ ).

Inspection of Figure 7B reveals that cycles of shorter wavelengths in mean test diameter occurred during the interval from 0 to $0.24 \mathrm{Ma}$, and that cycles of longer wavelengths occurred from 0.43 to $2.17 \mathrm{Ma}$. Cycles of shorter wavelengths in paleoenvironmental parameters during the late Pleistocene were also found by Hays et al. (1969) in the equatorial Pacific and by Briskin and Berggren (1975) in the tropical North Atlantic. Comparison of the late Pleistocene portions of the EPR and tropical North Atlantic (Briskin and Berggren, 1975) time series indicated that the similarity in the cycles of short wavelength probably was not the result of chance
A

Number of Occurrences
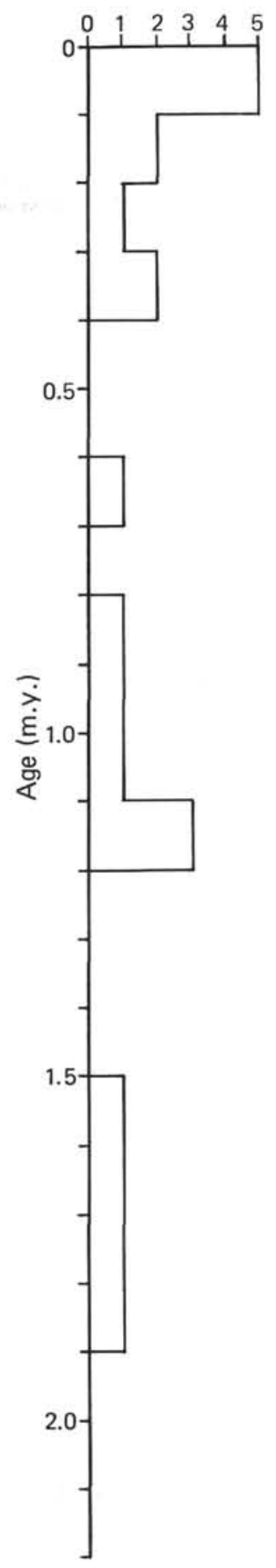

B $\bar{x}$ Diameter $(\times 100 \mu \mathrm{m})$
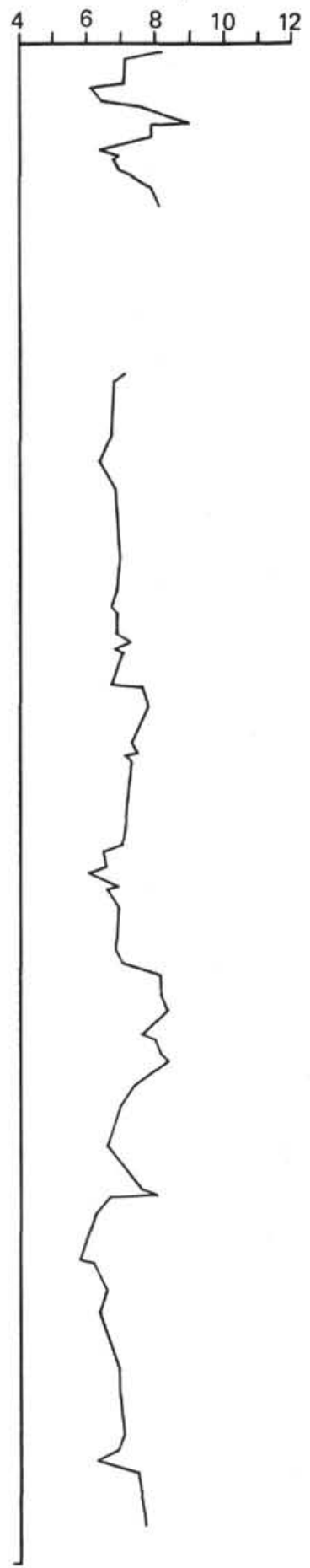

Figure 7. A. Histogram illustrating the number of occurrences of Turborotalia (Neogloboquadrina) pachyderma (Ehrenberg), Globigerina bulloides d'Orbigny, and Truncorotalia inflata (d'Orbigny) 'coldwater" species per 10-ka intervals at the EPR. B. Graph showing the mean $(\bar{x})$ diameter $(\times 100 \mu \mathrm{m})$ of the tests of "Orbulina universa d'Orbigny" at the $E P R$ as a three-point moving average versus time (Ma). 
TABLE 4

Mean Diameter of "Orbulina universa d'Orbigny" in EPR samples

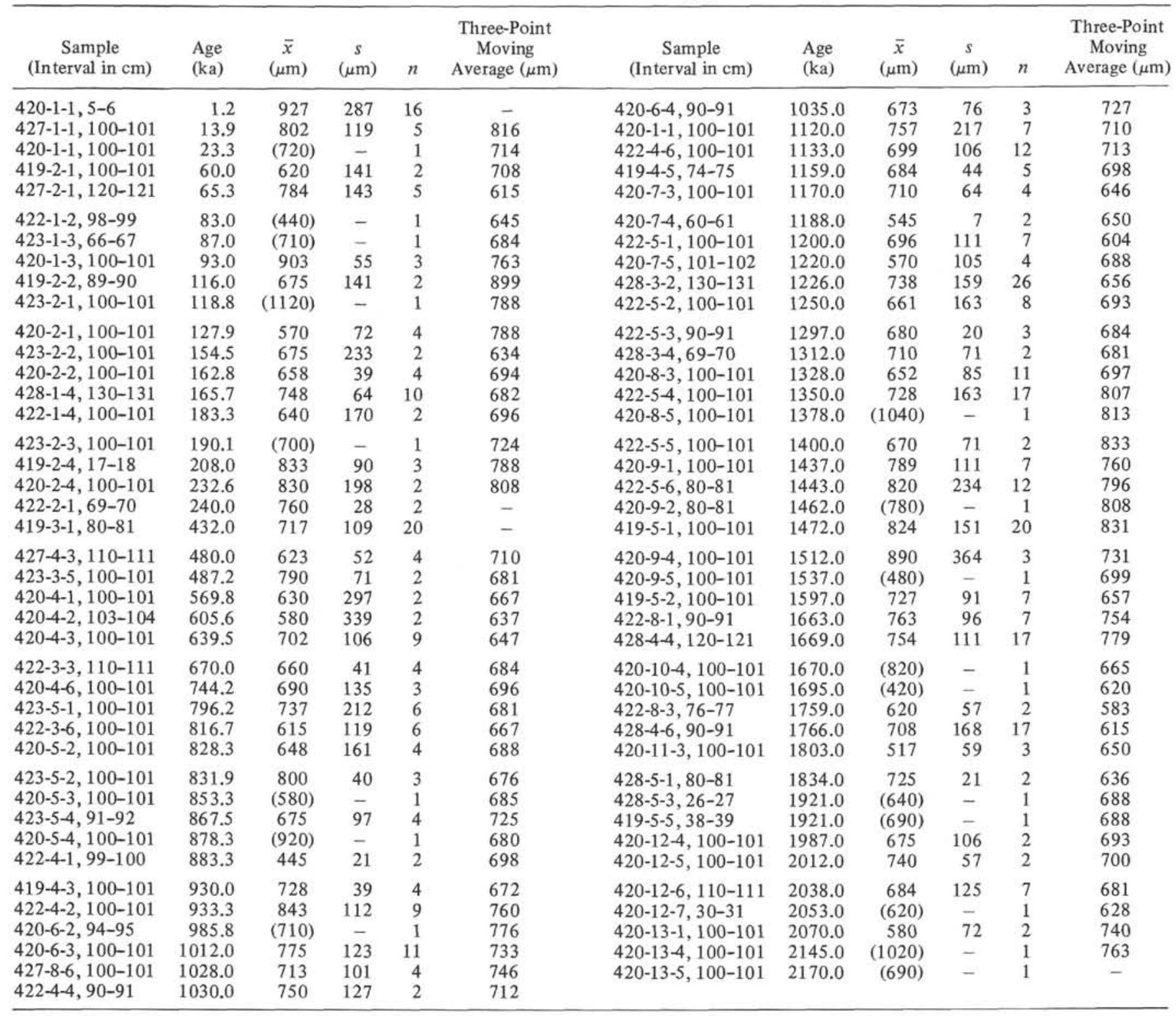

$\left(\chi^{2}=5.00,1 d f, P=0.97\right)$. The wavelength of the cycles in mean test diameter of "Orbulina universa" over the past $240 \mathrm{ka}$ at the EPR was about $10 \mathrm{ka}$ and approximates the wavelength of climatic cycles that have been correlated with orbital eccentricity (Broecker and Van Donk, 1970; Hays et al., 1976).

Comparison of the cycles of longer wavelength in mean diameter of "Orbulina universa"' (Figure 7B) with the occurrences of the "cold-water" species (Figure 7A) indicates a correlation between these two environmental indicators. This relationship not only supports the reality of these cycles of longer wavelength in the environment at the EPR, but also suggests that "Orbulina universa" and the "cold-water" species may have been responding to the same environmental factor(s). Briskin and Berggren (1975) illustrate cycles of longer wavelengths in their tropical North Atlantic time series from about $0.25 \mathrm{Ma}$ to $1.75 \mathrm{Ma}$. Even though no correlation exists between the cycles of longer wavelengths of the EPR and tropical North Atlantic time series, the fact that both time series illustrate cycles of longer wavelengths suggests that environmental cycles of longer period may have characterized both the Pacific and Atlantic Oceans throughout much of the Pleistocene and at least upper Pliocene.

\section{Upper Pleistocene Hiatuses in Sediment Recovery}

When the distributions of the planktonic foraminiferal species were plotted by using the chronology established at each EPR site, two hiatuses in the occurrence of planktonic foraminifers became evident. At each EPR site a hiatus was found between 240 and $345 \mathrm{ka}$ and between 485 and $570 \mathrm{ka}$. Inspection of the coring records revealed that these intervals were not cored at Sites 427 
and 428 , but were cored at Sites 419, 420, 422, and 423 . The hiatuses at the latter four sites were the result of not recovering cored sediment.

Inspection of the core descriptions (this volume) reveals that the hiatus from 240 to $345 \mathrm{ka}$ is bounded, both above and below, by foraminifer-nannofossil oozes that are described as either being severely disturbed or soupy. The hiatus from 485 to $570 \mathrm{ka}$ is bounded by oozes, nannofossil-foraminifer, nannofossil and nannofossil-radiolarian, that are described as being moderately to severely disturbed.

Several physical phenomena may result in sediment not being retained in the core barrel: (1) dissolution of the sediment by either the drilling mud or salt water, (2) gases propping open the section, (3) inhomogeneous sediment, and (4) the sediment having a high porosity and water content. High-porosity sediment containing considerable water appears to be the most probable cause of the sediment not being retained in the core barrels at the EPR sites.

A mechanism for producing high-porosity sediment capable of containing a considerable amount of water is present in the region of the EPR sites. These sites are either near or below the lysocline or CCS today. Dissolution of the carbonate fraction would probably result in a decrease in grain size and concurrent increase in porosity of the residual sediment. This brown clay would then have the potential for a relatively high water content producing a sediment that might not have enough cohesiveness to be retained in the core barrel. If this interpretation is correct, the hiatuses in sediment recovery on the EPR at 240 to $345 \mathrm{ka}$ and 485 to $570 \mathrm{ka}$ may represent periods of shoaling of the lysocline and/or CCS.

\section{GSC}

\section{Introduction}

Planktonic foraminifers were analyzed at Site 424 , about $22 \mathrm{~km}$ south of the GSC in the hydrothermal mounds field (Hekinian et al., 1978; Natland et al., 1979; Corliss et al., 1979), and Site 425, about $62 \mathrm{~km}$ north of the GSC (Figure 2). Holes 424 and 424A were drilled on hydrothermal mounds, whereas Hole 424B was drilled in an area between mounds (Hekinian et al., 1978; Natland et al., 1979). Holes 424, 424A, and 424B were continuously cored with 93 per cent, 45 per cent, and 84 per cent sediment recovery, respectively (Figure 4). No foraminiferal datum events were positively identified in Holes 424, 424A, and 424B. Datum I generally has not been recognized in this study because "Sphaeroidinella dehiscens" was never very abundant. More " $S$. dehiscens" were found in the oldest sample analyzed in Hole 424B $(27.75 \mathrm{~m})$. If this does represent Datum I, the oldest sediment recovered in Hole 424B may be close to $0.7 \mathrm{Ma}$. This age agrees well with the estimate of crustal age derived from magnetochrons (Hekinian et al., 1978).

Site 425 was not continuously cored ( $55 \%$ cored) and in the cored sections sediment recovery was 87 per cent, resulting in only 48 per cent of the sedimentary stratigraphic section being recovered (Figure 4). Neither "Sphae- roidinella dehiscens" nor Pulleniatina obliqueloculata finalis were common at Site 425, so that it was not possible to identify either Datum event I or II. Globigerinoides quadrilobatus fistulosus, Globigerinoides obliquus, and Pulleniatina primalis occurred in the oldest sample analyzed at Site $425(73.1 \mathrm{~m})$ but did not occur in a sample at 68.3 meters. This places the Pliocene/Pleistocene boundary between 68.3 and 73.1 meters at Site 425 . The extrapolated basalt basement age of $1.86 \mathrm{Ma}$ agrees well with the magnetochronology and is slightly older than the Olduvai event (Hekinian et al., 1978).

\section{Thanatocoenoses}

In general, the planktonic foraminiferal thanatocoenoses at the GSC sites were very well preserved. The only exception to this was found in the green, clay-rich muds associated with the hydrothermal mounds field where species richness was reduced (Figure 6). The GSC sites were drilled at depths of $\leq 2850$ meters, and it would appear that the lysocline did not shoal to this depth during the past $1.9 \mathrm{Ma}$ in this area.

Autochthonous gypsum was found in samples from Holes 424 and 425 (Figure 6). The GSC samples containing gypsum did not exhibit a decrease in planktonic foraminiferal species richness as did the gypsum containing samples at the EPR sites. This suggests that the dissolution of planktonic foraminifers at EPR sites was not related to the processes associated with gypsum genesis.

Finally, there did not appear to be any significant mixing of planktonic foraminiferal thanatocoenoses at the GSC sites. This, combined with the generally high quality of preservation, suggests that the vicinity of Site 425 in the Panama Basin may have excellent potential for providing a Pleistocene biostratigraphic section for the equatorial eastern Pacific. It is unfortunate that sediment coring was discontinuous at Site 425 .

\section{Green, Clay-Rich Mud}

Ten samples of the green mud from Holes 424 and 424B were analyzed for planktonic foraminifers. Three of these samples contained no planktonic foraminifers, and the remaining samples had species richnesses ranging from 1 to 22 species (Figure 6). The majority of these samples were characterized by few species and individuals of foraminifers. Both dissolution-liable and dissolution-resistant species occurred in most of the samples.

Figure 6 indicates that higher species richness generally characterized the oldest samples of green mud, and that species richness was generally reduced in the younger samples. This suggests that either there was an increase in the rate of production of green mud sometime after initiation of the hydrothermal system or there was a decrease in the $p \mathrm{H}$ of the hydrothermal fluids (Krauskopf, 1957; Hoffert et al., 1978; Natland et al., 1979) during the evolution of the hydrothermal system. Chemical analyses of green mud samples (Hekinian et al., 1978) did not indicate any statistically significant changes in the composition of the green mud through time. This indicates that variations in species richness probably reflect 
temporal variation in the rate of production of the green mud.

\section{SYSTEMATICS}

The late Neogene planktonic foraminifers identified at Leg 54 sites will be classified on the following pages, using the taxonomic philosophy of phylogenetic relationships (Steineck and Fleisher, 1978, and references therein). My concepts of the phylogenetic relationships of the late Neogene foraminifers are derived primarily from the works of Lipps (1966), Banner and Blow (1967), Parker (1967), Berggren (1968), Cifelli (1969), King and Hare (1972), Fleisher (1974), Kennett (1976), Steineck and Fleisher (1978), and my own personal biases. The biostratigraphic ranges of the taxa at the Leg 54 sites are summarized in Figure 8. Illustrations of the taxa may be found in Blow (1969), Brönnimann and Resig (1971), Jenkins and Orr (1972), Stainforth et al. (1975), and Quilty (1976).

\section{Superfamily GLOBIGERINACEA Carpenter, Parker \& Jones, 1862}

Family CHILOGUEMBELINIDAE Reiss, 1963

Genus STREPTOCHILUS Brönnimann \& Resig, 1971

Streptochilus sp.

Remarks: The four specimens of this species all have an aperture similar to that of Streptochilus. The species differs from the four species found by Brönniman and Resig (1971) in its early chambers being inflated and in having a lower length to width ratio $(\bar{x}=0.99, s=$ 0.20 ). The length of the four individuals ranged from $100 \mu \mathrm{m}$ to 180 $\mu \mathrm{m}$, and their width varied from $140 \mu \mathrm{m}$ to $160 \mu \mathrm{m}$. All four specimens were found at EPR sites.

Occurrence: EPR Samples 420-7-4, 60-61 cm, (57.1 m); 421-1-6, $100-101 \mathrm{~cm} \mathrm{(7} \mathrm{m);} \mathrm{427-4-6,} \mathrm{120-121} \mathrm{cm} \mathrm{(4.7} \mathrm{m);} \mathrm{and} \mathrm{428-4-6,} \mathrm{90-91} \mathrm{cm}$ $(56.4 \mathrm{~m})$.

Stratigraphic Range: PL6 to upper Pleistocene.

\section{Family GLOBOROTALIIDAE Cushman, 1927 Subfamily GLOBOROTALIINAE Cushman, 1927}

Genus TURBOROTALIA Cushman \& Bermúdez, 1949

Remarks: Turborotalia is used here in the same manner as defined by Fleisher (1974). It includes those phylogenetically related species that have a cancellate wall texture (Steineck and Fleisher, 1978) and mainly an umbilical to extra-umbilical or peripheral aperture which is bordered by a lip or rim. As defined, Turborotalia includes the $T$. opima nana (Bolli) - T. acostaensis humerosa (Takayanagi and Saito) lineage (Berggren, 1968; Blow, 1969; Fleisher, 1974).

Turborotalia (Turborotalia) acostaensis (Blow), 1959

Occurrence: EPR Sites 420 and 428.

Stratigraphic Range: PL6.

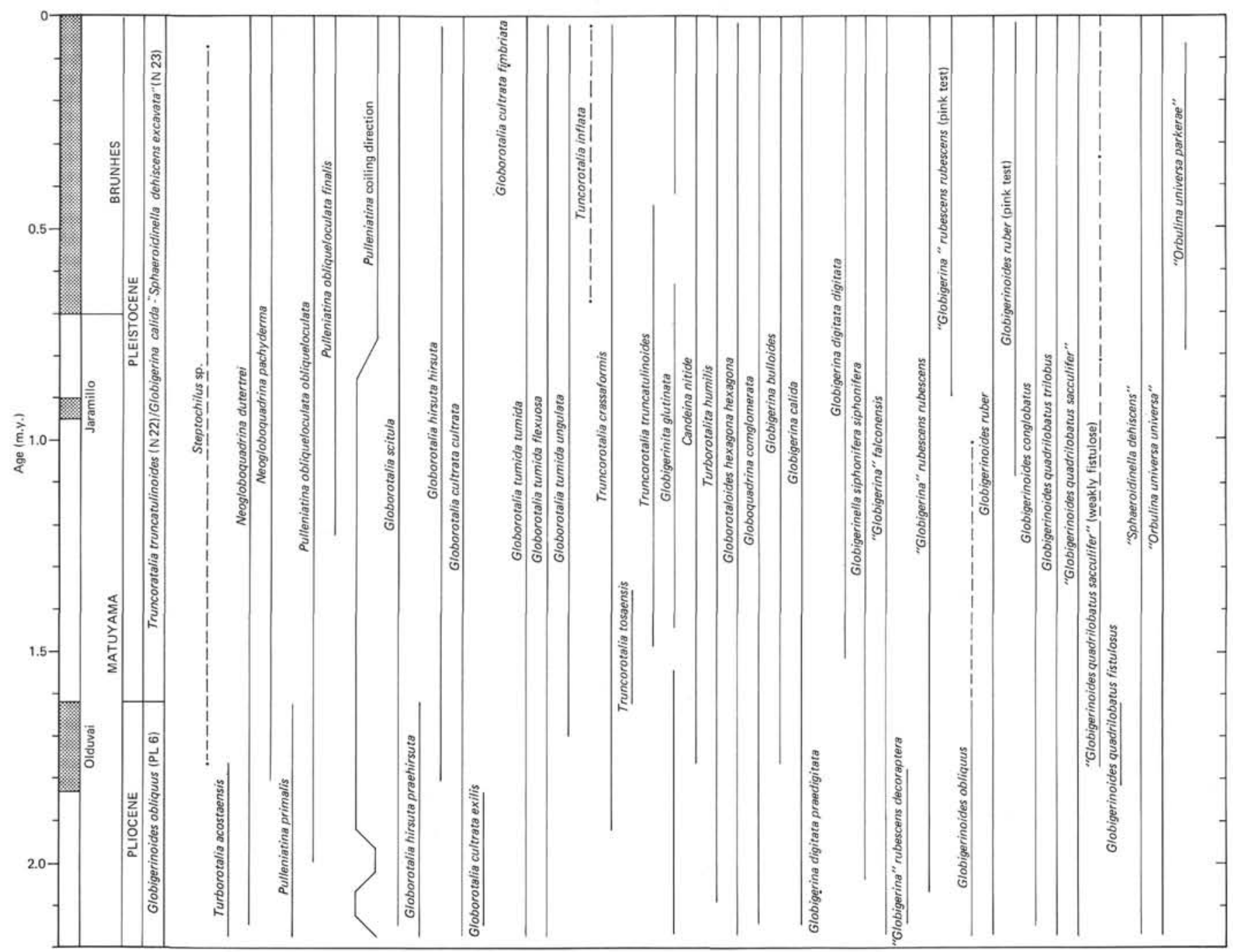

Figure 8. Biochronology of the planktonic foraminiferal species found at Leg 54 EPR and GCS sites. 


\section{Turborotalia (Neogloboquadrina) dutertrei} (d'Orbigny), 1839

Remarks: This species was common at all Leg 54 sites. Occurrence: All Leg 54 sites.

Stratigraphic Range: PL6 to Pleistocene.

\section{Turborotalia (Neogloboquadrina) pachyderma}

(Ehrenberg), 186

Remarks: A few dextrally coiled individuals were found at some of the EPR and GSC sites.

Occurrence: EPR Sites 419 and 420; GSC Hole 424.

Stratigraphic Range: PL 6 to Pleistocene at EPR sites; upper Pleistocene at GSC hole.

\section{Genus PULLENIATINA Cushman, 1927}

Remarks: Classified with the turborotalids because of a similarity between the morpholoy of juvenile individuals of Pulleniatina and the turborotalids, which appears to support the derivation of the genus from the Turborotalia acostaensis lineage (Banner and Blow, 1967). Pulleniatina species were right coiled throughout the Brunhes Epoch until about $0.8 \mathrm{Ma}$, when there was a change to left coiling. Left coiling persisted until about $2.0 \mathrm{Ma}$, when there was a short interval of right coiling. The fluctuations in coiling direction between 1 and $2 \mathrm{Ma}$ that were found by Saito (1976) in Indo-Pacific populations of Pulleniatina were not found at the Leg 54 sites.

\section{Pulleniatina primalis Banner \& Blow, 1968}

Occurrence: EPR Sites 419 and 420; GSC Site 425.

Stratigraphic Range: PL6; became extinct at the Pliocene/Pleistocene boundary.

\section{Pulleniatina obliqueloculata obliqueloculata (Parker \& Jones), 1862}

Occurrence: All Leg 54 sites.

Stratigraphic Range: PL6 to Pleistocene; first appears at Leg 54 sites at about $2 \mathrm{Ma}$.

\section{Pulleniatina obliqueloculata finalis} Banner \& Blow, 1967

Remarks: This species was not abundant at most of the sites. The first appearance of Pulleniatina obliqueloculata finalis at Leg 54 sites occurred at about $0.8 \mathrm{Ma}$. Therefore, it was not possible to identify Datum II in this study.

Occurrence: All Leg 54 sites, except EPR Sites 422, 423, and 427.

Stratigraphic Range: Pleistocene; $0.8 \mathrm{Ma}$ to present.

Genus GLOBOROTALIA Cushman, 1927

Remarks: Globorotalia is used here to include those phylogenetically related species that have a finely perforate-smooth wall texture (Steineck and Fleisher, 1978), generally biconvex test with an extra-umbilical aperture with a flap-like lip. As defined, Globorotalia would include the $G$. peripheroronda Blow and Banner - $G$. fohsi Cushman and Ellisor, G. scitula praescitula Blow - G. tumida, and G. scitula - G. hirsuta hirsuta lineages (Berggren, 1968; Fleisher, 1974; Steineck and Fleisher, 1978).

\section{Globorotalia scitula (Brady), 1882}

Occurrence: All Leg 54 sites.

Stratigraphic Range: PL6 to Pleistocene; found only in the upper Pleistocene at the GSC sites.

\section{Globorotalia hirsuta praehirsuta Blow, 1969}

Occurrence: EPR Sites 420 and 428

Stratigraphic Range: PL6; became extinct at the Pliocene/Pleistocene boundary.

\section{Globorotalia hirsuta hirsuta (d'Orbigny), 1839}

Occurrence: All Leg 54 sites.

Stratigraphic Range: Pleistocene; first appears at Pliocene/Pleistocene boundary.

\section{Globorotalia cultrata cultrata (d’Orbigny), 1839}

Occurrence: All Leg 54 sites.

Stratigraphic Range: PL6 to Pleistocene.

Globorotalia cultrata exilis Blow, 1969

Occurrence: EPR Sites 419 and 420.

Stratigraphic Range: PL6; became extinct at about $1.8 \mathrm{Ma}$.

Globorotalia cultrata fimbriata (Brady), 1884

Occurrence: EPR Sample 419-2-2, 89-90 cm (2.9 m). Stratigraphic Range: Upper Pleistocene.

Globorotalia tumida tumida (Brady), 1877

Occurrence: All Leg 54 sites.

Stratigraphic Range: PL6 to Pleistocene.

Globorotalia tumida flexuosa (Koch), 1923

Occurrence: All Leg 54 sites; not found in GSC Hole 424A.

Stratigraphic Range: PL 6 to Pleistocene; last appearance at about $20 \mathrm{ka}$.

\section{Globorotalia tumida ungulata Bermúdez, 1960}

Remarks: Individuals of the Globorotalia cultrata-Globorotalia tumida complex that live in near-surface waters have lightly constructed tests. A thin-walled test appears to be the only criterion that differentiates $G$. ungulata from $G$. tumida. For this reason I consider $G$. ungulata to be a variant of G. tumida, and probably it should not even be recognized as a subspecies of $G$. tumida. Because of the thinwalled test, it is highly probable that the first appearance of $G$. tumida ungulata in the biostratigraphic record is controlled by diagenesis.

Occurrence: All Leg 54 sites. Ma.

Stratigraphic Range: PL6 to Pleistocene; first appears at about 1.7

\section{Genus TRUNCOROTALIA Cushman \& Bermúdez, 1949}

Remarks: Truncorotalia is used here to include those phylogenetically related species that have a finely perforate-smooth wall texture (Steineck and Fleisher, 1978), generally planoconico test with an extra-umbilical aperture with a flap-like lip. As defined, Truncorotalia would include the $T$. miozea Finlay - $T$. truncatulinoides lineage (Berggren, 1968; Fleisher, 1974; Steineck and Fleisher, 1978).

\section{Truncorotalia inflata (d’Orbigny), 1839}

Occurrence: EPR Samples 420-1-1, 100-101 cm (1 m) and 420-4-4, $100-101 \mathrm{~cm}(29 \mathrm{~m})$.

Stratigraphic Range: Upper Pleistocene.

\section{Truncorotalia crassaformis (Galloway \& Wissler), 1927}

Remarks: More common at GSC sites than at EPR sites. 427.

Occurrence: Occurs at all Leg 54 sites, except Sites 422, 423, and

Stratigraphic Range: PL6 to Pleistocene; first appearance at about $1.8 \mathrm{Ma}$.

\section{Truncorotalia tosaensis Takayanagi \& Saito, 1962}

Occurrence: EPR Sample 420-9-1, 100-101 cm (72 m); GSC Samples 425-5-1, 110-111 cm (63.6 m) and 425-6-1, 110-111 cm $(73.1 \mathrm{~m})$.

Stratigraphic Range: Lower Pleistocene; first appearance at about 1.6 Ma and last appearance at approximately 1.4 Ma.

\section{Truncorotalia truncatulinoides (d'Orbigny), 1839}

Remarks: Found only at GSC sites.

Occurrence: GSC Holes 424, 424A, and 425.

Stratigraphic Range: Pleistocene. 


\author{
Subfamily CANDEININAE Cushman, 1927 \\ Genus GLOBIGERINITA Brönnimann, 1951 \\ Globigerinita glutinata (Egger), 1893
}

Remarks: This is one of the most abundant species found at the Leg 54 sites. Both individuals with and without a bulla are abundant. Occurrence: All Leg 54 sites.

Stratigraphic Range: PL6 to Pleistocene.

Genus CANDEINA d'Orbigny, 1839

Candeina nitida d'Orbigny, 1839

Occurrence: Occurs at all Leg 54 sites, except EPR Sites 423 and 427, and GSC Hole 424A.

Stratigraphic Range: PL6 to Pleistocene; first appearance at about $1.75 \mathrm{Ma}$.

\section{Genus TURBOROTALITA Blow \& Banner, 1962 \\ Turborotalita humilis (Brady), 1884}

Remarks: Found only at the EPR sites.

Occurrence: All EPR sites.

Stratigraphic Range: PL6 to Pleistocene.

Family CATAPSYDRACIDAE Bolli, Loeblich \& Tappan, 1957

Genus GLOBOROTALOIDES Bolli, 1957

Globorotaloides hexagona hexagona (Natland), 1938

Occurrence: All Leg 54 sites.

Stratigraphic Range: PL6 to Pleistocene.

Genus GLOBOQUADRINA Finlay, 1947

Globoquadrina conglomerata (Schwager), 1866

Occurrence: All Leg 54 sites.

Stratigraphic Range: PL6 to Pleistocene.

Family GLOBIGERINIDAE Carpenter, Parker \& Jones, 1862

Genus GLOBIGERINA d'Orbigny, 1826

Remarks: Globigerina is used in the same restricted manner as defined by Fleisher (1974). The genus includes those phylogenetically related species that have a spinose wall texture (Steineck and Fleisher, 1978), umbilical aperture with an imperforate rim, and generally loosely attached chambers. As defined, Globigerina would include the $G$. praebulloides Blow - $G$. bulloides and $G$. praedigitata - $G$. digitata lineages (Parker, 1967; Blow, 1969; Fleisher, 1974).

Globigerina bulloides d'Orbigny, 1826 425 .

Occurrence: EPR Sites 419, 420 and 428; GSC Hole 424 and Site

Stratigraphic Range: PL6 to Pleistocene; first appearance at about $1.75 \mathrm{Ma}$.

Globigerina calida Parker, 1962

Occurrence: All Leg 54 sites.

Stratigraphic Range: PL6 to Pleistocene.

Globigerina digitata praedigitata Parker, 1967

Occurrence: EPR Sample 420-13-1, 100-101 cm (110 m). Stratigraphic Range: PL6.

Globigerina digitata digitata Brady, 1879

Remarks: Most commonly occurs at GSC sites; rare at EPR sites. Occurrence: All Leg 54 sites, except EPR Site 427.

Stratigraphic Range: Pleistocene; first appearance at about 1.5 Ma.

Genus GLOBIGERINELLA Cushman, 1927

Globigerinella siphonifera siphonifera (d'Orbigny), 1839

Occurrence: All Leg 54 sites.

Stratigraphic Range: PL6 to Pleistocene.
Genus "GLOBIGERINA" non GLOBIGERINA d'Orbigny

Remarks: Fleisher (1974) pointed out that species with a cancellate wall texture have been classified as Globigerina, which has a spinose wall texture, upon the basis of their possessing a globigeriniform test with an umbilical aperture. He suggested that (Globigerina) species with cancellate wall texture and spinose wall texture represented separate evolutionary complexes, which had converged on the globigeriniform test morphology, and probably represented two distinct genera. "Globigerina" includes those phylogenetically related species that have a cancellate wall texture (Fleisher, 1974), umbilical aperture with a thickened imperforate rim, and generally appressed chambers. Fleisher (1974) recognized three phylogenetic lineages within the cancellate "Globigerina," including the "G." woodi woodi (Jenkins) " $G$." rubescens rubescens lineage.

"Globigerina" falconensis (Blow), 1959

Occurrence: All Leg 54 sites.

Stratigraphic Range: PL6 to Pleistocene.

"Globigerina" rubescens decoraptera (Takayanagi \& Saito), 1962

Occurrence: EPR Site 420.

Stratigraphic Range: PL6; last appearance at about $1.8 \mathrm{Ma}$.

\section{"Globigerina" rubescens rubescens (Hofker), 1956}

Remarks: Both pink and white tests were found at all Leg 54 sites. The pink tests were restricted to the past $0.9 \mathrm{Ma}$. Parker (1967) discussed the transition from white to pink tests during the Pleistocene and could not determine whether this transition represented an evolutionary or diagenetic event. Pink tests also occur in Globigerinoides ruber. In an attempt to discern whether the transition from white to pink tests represents an evolutionary or diagenetic event, the oldest occurrence of " G." rubescens rubescens and G. ruber were compared in each hole. In 50 per cent of the holes the transition from white to pink test was coeval in both species, and in the rest of the holes there was no consistent temporal relationship. This suggests that the transition from white to pink test in both " $G$." rubescens rubescens and $G$. ruber probably represents a diagenetic event.

Occurrence: All Leg 54 sites.

Stratigraphic Range: PL6 to Pleistocene.

\section{Genus GLOBIGERINOIDES Cushman, 1927 \\ Globigerinoides obliquus Bolli, 1957}

Remarks: Globigerinoides obliquus was not divided into subspecies in this study, because there appeared to be a complete intergradation between $G$. obliquus obliquus and $G$. obliquus extremus. $G$. obliquus last appears at the Pliocene/Pleistocene boundary at both the EPR and GSC, except for a single specimen that was found at about $1 \mathrm{Ma}$ (EPR) Sample 420-6-3, 100-101 cm (46.5 m).

Occurrence: EPR Sites 419, 420, and 428; GSC Site 425.

Stratigraphic Range: PL6; last appearance at the Pliocene/Pleistocene boundary, except for a single individual at about $1 \mathrm{Ma}$ (see preceding Remarks).

\section{Globigerinoides ruber (d'Orbigny), 1839}

Remarks: This was the most abundant species occurring at Leg 54 sites. Both pink and white tests were found at all sites. Bé and Tolderlund (1971) indicated that pink pigment in the test of Globigerinoides ruber appeared to be an ecophenotypic feature, with pink-test $G$. ruber occurring in warmer surface waters than white-test $G$. ruber. Bé and Tolderlund (1971) also indicated that populations of pink-test $G$. ruber were lacking from the Indo-Pacific plankton. The youngest occurrence of $G$. ruber with pink tests in this study was at EPR Site 427 at an age of about $13 \mathrm{ka}$. The first appearance of pink-test $G$. ruber at Leg 54 sites was at about $1.1 \mathrm{Ma}$ and probably represents a diagenetic event (See Remarks for "Globigerina" rubescens rubescens).

Occurrence: All Leg 54 sites.

Stratigraphic Range: PL6 to Pleistocene.

\section{Globigerinoides conglobatus (Brady), 1879}

Occurrence: All Leg 54 sites,

Stratigraphic Range: PL6 to Pleistocene. 


\section{Globigerinoides quadrilobatus trilobus (Reuss), 1850}

Remarks: It appears that there is considerable ecophenotypic variation within the Globigerinoides quadrilobatus trilobus population. Bé (1965) and Jones (1971) indicate that G. quadrilobatus trilobus lives over a considerable depth range, and there are morphological responses to depth in the water column. G. quadrilobatus trilobus s. 1. appears to represent the shoaler ecophenotype, whereas with increasing depth a sac-like final chamber may be added to derive the "G. quadrilobatus sacculifer" ecophenotype (Bé, 1965; Jones, 1971). It also appears that these ecophenotypes have been in existence since the development of $G$. quadrilobatus trilobus, because they both apparently have the same stratigraphic range of N6 to N23 (Blow, 1969).

Occurrence: All Leg 54 sites.

Stratigraphic Range: PL6 to Pleistocene.

“'Globigerinoides quadrilobatus sacculifer (Brady), 1877"

Remarks: This "subspecies" is probably an ecophenotypic variant of Globigerinoides quadrilobatus trilobus (see preceding Remarks for G. quadrilobatus trilobus). Included in " G. quadrilobatus sacculifer" are forms that are both typical and weakly fistulose. Weakly fistulose forms occur at EPR Sites 419, 420, and 422, and GSC Sites 424 and 425. The stratigraphic range of the weakly fistulose forms extends from the upper part of PL6 (first appearance at about $1.75 \mathrm{Ma}$ ) to the present. The weakly fistulose forms are most common in the interval from about 1.75 to $1.2 \mathrm{Ma}$. There is no apparent difference between the weakly fistulose forms that occur in the upper Pliocene and those occurring in the Pleistocene. It is not improbable that the fistulose form may represent another ecophenotype of $G$. quadrilobatus trilobus.

Occurrence: All Leg 54 sites.

Stratigraphic Range: PL6 to Pleistocene.

\section{Globigerinoides quadrilobatus fistulosus (Schubert), 1910}

Remarks: Typical Globigerinoides quadrilobatus fistulosus are rare in this study and occur only at two EPR sites in upper Pliocene sediments. Within the interval from about 1.75 to $1.62 \mathrm{Ma}$, both typical $G$. quadrilobatus fistulosus and weakly fistulose " $G$. quadrilobatus sacculifer" occur together. Parker (1967) also found weakly and strongly fistulose forms occurring together in Pacific cores. She suggests that an evolutionary series from weakly fistulose to strongly fistulose forms may be found in G. quadrilobatus fistulosus (Text-figure 4 in Parker, 1967). It appears to me that a more likely explanation for the fistulose morphology is that it represents another ecophenotypic variant within the $G$. quadrilobatus trilobus population which is most strongly expressed during the Pliocene.

Occurrence: EPR Samples 420-10-5, 100-101 cm (87.5 m); 420-10-6, $100-101 \mathrm{~cm}(89 \mathrm{~m})$; and 428-10-6, 90-91 cm (56.4 m).

Stratigraphic Range: PL6; last appearance at Pliocene/Pleistocene boundary.

\section{"Genus SPHAEROIDINELLA Cushman, 1927"}

Remarks: "Sphaeroidinella dehiscens" is the type species for the genus. Because Bé (1965) and Bé and Hemleben (1970) have shown that "Sphaeroidinella dehiscens" is a terminal growth stage of some Globigerinoides quadrilobatus trilobus, "Sphaeroidinella" is not a valid genus.

\section{“Sphaeroidinella dehiscens (Parker \& Jones), 1865"}

Remarks: It was not possible to differentiate between "Sphaeroidinella dehiscens dehiscens" and "S. dehiscens excavata" in this study, because a complete gradation existed between the two "subspecies."

" $S$. dehiscens" is primarily found in the plankton at meso- or bathypelagic depths (Bé, 1965; Bé and Hemleben, 1970; Jones, 1971). Bé (1965) and Bé and Hemleben (1970) illustrate that "S. dehiscens" is a growth stage of some Globigerinoides quadrilobatus trilobus. The dehiscens form develops by calcifying a smooth cortex over the spinose, cancellate wall-texture test of $G$. quadrilobatus trilobus. It, therefore, appears that " $S$. dehiscens" represents yet another ecophenotypic variant in the $G$. quadrilobatus trilobus population.

The fossil record seems to support the hypothesis that dehiscenstype variants developed early in the $G$. quadrilobatus trilobus lineage (Bé and Hemleben, 1970). It would appear that the "Sphaeroidinel- lopsis seminula (Schwager)" represents an early stage in the development of the smooth cortex (see Pl. 23 in Parker, 1967), which first originated during the early Burdigalian (N6). The smooth cortex became well developed by the middle Langhian (N13), as exemplified by "Sphaeroidinellopsis subdehiscens."

Occurrence: All Leg 54 sites; not found in GSC Hole 424A.

Stratigraphic Range: PL6 to Pleistocene.

\section{"'Genus ORBULINA d'Orbigny, 1839"'}

Remarks: Many authors have suggested that "Orbulina" may be polyphyletic, with the final obuline chamber being constructed by several different species or genera (Rhumbler, 1911; Bandy, 1966; Bandy et al., 1966; Parker, 1967). Bé et al. (1973) argue that the trochospiral stages within the orbuline chamber do not represent distinct species. Inspection of PI. 3 and 4 in Bé et al. (1973) reveals that trochospiral stages have either a spinose, smooth wall texture or spinose, cancellate wall texture. This strongly suggests the orbuline stage has been converged upon by at least two separate lineages (Steineck and Fleisher, 1978) and that "Orbulina" is polyphyletic.

I support the hypothesis that the orbuline stage in these lineages probably represents reproductive chambers (Bandy et al., 1966), which are analogous to those constructed by the polyphyletic "Tretomphalus" (Sliter, 1965).

\section{"Orbulina universa universa d'Orbigny, 1839"}

Occurrence: All Leg 54 sites.

Stratigraphic Range: PL6 to Pleistocene.

“Orbulina universa parkerae Brönnimann \& Resig, 1971”

Remarks: Most occurrences of "Orbulina universa parkerae" have been from the late Miocene and Pliocene (Brönnimann and Resig, 1971; Quilty, 1976). Parker (1967) did illustrate the subspecies from a core top (Recent) from the southeastern Pacific. "O. universa parkerae" was only found at the GSC sites in this study where it occurred in the Pleistocene section. Its first appearance occurred at about 0.8 $\mathrm{Ma}$, and its last appearance at the GSC sites was at about $50 \mathrm{ka}$.

Occurrence: Restricted to GSC sites.

Stratigraphic Range: Pleistocene.

\section{REFERENCES}

Bandy, O. L., 1966. Restriction of the "Orbulina" datum. Micropaleont., v. 12, p. 79-86.

Bandy, O. L., Ingle, J. C., and Frerichs, W. E., 1966. Geologic significance of isomorphism in planktonic foraminifera (abstract). Geol. Soc. Am. Spec. Paper, No. 87, p. 9.

Banner, F. T. and Blow, W. H., 1965. Progress in the planktonic foraminiferal biostratigraphy of the Neogene. $\mathrm{Na}$ ture, v. 208, p. 1164-1166.

1967. The origin, evolution and taxonomy of the foraminiferal genus Pulleniatina Cushman, 1927. Micropaleont., v. 13, p. 133-162.

Bayliss, D. D., 1969. The distribution of Hyalinea balthica and Globorotalia truncatulinoides in the type Calabrian. Lethaia, v. 2, p. 133-143.

1975. The stratigraphy of the type section for the Pliocene/Pleistocene boundary in Italy. Micropaleont. Spec. Publ., v. 1, p. 31-40.

Bé, A. W. H., 1965. The influence of depth on shell growth in Globigerinoides sacculifer (Brady). Micropaleont., v. 11, p. 81-97.

1977. An ecological, zoogeographic and taxonomic review of Recent planktonic foraminifera. In Ramsay, A. T. S. (Ed.), Oceanic Micropaleontology 1: London (Academic Press), p. 1-100.

Bé, A. W. H., Harrison, S. M., and Lott, L., 1973. Orbulina universal d'Orbigny in the Indian Ocean. Micropaleont., v. 19, p. 150-192.

Bé, A. W. H. and Hemleben, C., 1970. Calcification in a living planktonic foraminifer Globigerinoides sacculifer (Brady). N. Jb. Geol. Palaeont. Abh., v. 134, p. 221-234. 
Bé, A. W. H. and Tolderlund, D. S., 1971. Distribution and ecology of living planktonic foraminifera in surface waters of the Atlantic and Indian Oceans. In Funnell, B. M. and Riedel W. R. (Eds.), The Micropaleontology of Oceans: London (Cambridge University Press), p. 105-149.

Berger, W. H., 1970. Planktonic foraminifera: selective solution and the lysocline. Mar. Geol., v. 8, p. 111-138.

Berger, W. H. and Winterer, E. L., 1974. Plate stratigraphy and the fluctuating carbonate line. Internat. Assoc. Sediment. Spec. Publ., v. 1, p. 11-48.

Berggren, W. A., 1968. Phylogenetic and taxonomic problems of some Tertiary planktonic foraminiferal lineages. Tulane Studies Geol., v. 6, p. 1-22.

1973. The Pliocene time scale: calibration of planktonic foraminiferal and calcareous nannoplankton zones. Nature, v. 243, p. 391-397.

Berggren, W. A. and Van Couvering, J. A., 1978. Biochronology. Studies in Geol., v. 6, p. 39-55.

Blow, W. H., 1969. Late middle Eocene to Recent planktonic foraminiferal biostratigraphy. Internat. Conf. Planktonic Microfossils (1st) (Geneva), p. 199-422.

Bolli, H. M., 1966. Zonations of Cretaceous to Pliocene marine sediments based on planktonic foraminifera. Bol. Inform. Assoc. Venez. Geol., Mineria Petroleo., v. 9, p. 3-32.

Bradshaw, J. S., 1959. Ecology of living planktonic foraminifera in the north and equatorial Pacific Ocean. Contrib. Cushman Found. Foram. Res., v. 10, p. 25-64.

Briskin, M. and Berggren, W. A., 1975. Pleistocene stratigraphy and quantitative paleooceanography of tropical North Atlantic core V 16-205. Micropaleont. Spec. Publ., v. 1 , p. $167-198$.

Broecker, W. S. and Van Donk, J., 1970. Insolation changes, ice volumes, and $\mathrm{O}^{18}$ record in deep-sea cores. Rev. Geophys. Space Phys., v. 8, p. 169-198.

Brönnimann, P. and Resig, J., 1971. A Neogene globigeracean biochronologic time-scale of the southwestern Pacific. In Winterer, E. L., et al., 1977. Initial Reports of the Deep Sea Drilling Project, v. 7, Pt. 2: Washington (U. S. Government Printing Office), p. 1235-1469.

Cifelli, R., 1969. Radiation of Cenozoic planktonic foraminifera. System. Zool., v. 18, p. 154-168.

Connell, J. H., 1978. Diversity in tropical rain forests and coral reefs. Science, v. 199, p. 1302-1310.

Corliss, J. B., Dymond, J., Gordon, L. I., Edmon, J. M., Von Herzen, R. P., Ballard, R. D., Green, K., Williams, D., Bainbridge, A., Crane, K., and van Andel, Tj. H., 1979. Submarine thermal springs on the Galapágos rift. Science, v. 203, p. 1073-1083.

Fleisher, R. L., 1974. Cenozoic planktonic foraminifera and biostratigraphy, Arabian Sea Deep Sea Drilling Project Leg 23A. In Whitmarsh, R. B., Weser, O. E., Ross, D. A., et al., Initial Reports of the Deep Sea Drilling Project, v. 23: Washington (U. S. Government Printing Office). p. 10011072.

Haq, B. U., Berggren, W. A. and Van Couvering, J. A., 1977. Corrected age of the Pliocene/Pleistocene boundary. Nature, v. 269, p. 483-488.

Hays, J. D., Imbrie, J., and Shackleton, N. J., 1976. Variations in the earth's orbit: pacemaker of the ice ages. Science, v. 194, p. 1121-1132.

Hays, J. D., Saito, T. Opdyke, N. D., and Burckle, L. D., 1969. Pliocene-Pleistocene sediments of the equatorial Pacific: their paleomagnetic, biostratigraphic, and climatic record. Geol. Soc. Am. Bull., v. 80, p. 1481-1514.

Hays, J. D. and Shackleton, N. J., 1976. Globally synchronous extinctions of the radiolarian Stylatractus universus. Geology, v. 4, p. 649-652.
Hekinian, R., Rosendahl, B. R., Cronan, D. S., Dmitriev, Y., Fodor, R. V., Goll, R. M., Hoffert, M., Humphris, S. E., Mattey, D. P., Natland, J., Peterson, N., Roggenthen, W., Schrader, E. L., Srivastava, R. K., and Warren, N., 1978. Hydrothermal deposits and associated basement rocks from the Galapagos spreading center. Oceanolog. Acta, v. 1, p. 473-482.

Hoffert, M., Perseil, A., Hekinian, R., Choukroune, P., Needham, H. D., Francheteau, J., and Le Pichon, X., 1978. Hydrothermal deposits sampled by diving saucer in Transform Fault "A" near $37^{\circ} \mathrm{N}$ on the Mid-Atlantic Ridge, Famous area. Ibid., v. 1, p.73-86.

Hutchinson, G. E., 1961. The paradox of the plankton. Amer. Nat., v. 95, p. 137-145.

Jenkins, D. G. and Orr, W. N., 1972. Planktonic foraminiferal biostratigraphy of the eastern equatorial PacificDSDP Leg 9. In Hays, J. D., et al., Initial Reports of the Deep Sea Drilling Project, v. 9: Washington (U. S. Government Printing Office), p. 1059-1193.

Jones, J. I., 1971. The ecology and distribution of living planktonic foraminifera in the Straits of Florida. Miami Geol. Soc. Mem., v. 1, p. 175-190.

Kaneps, A. G., 1973. Cenozoic planktonic foraminifera from the eastern equatorial Pacific Ocean. In van Andel, Tj. H., Heath, G. H., et al, Initial Reports of the Deep Sea Drilling Project, v. 16: Washington (U. S. Government Printing Office), p. 713-745.

Kennett, J. P., 1976. Phenotypic variation in some Recent and Late Cenozoic planktonic foraminifera. In Hedley, R. H., and Adams, C. G. (Eds.), Foraminifera 2: London (Academic Press), p. 111-170.

King, K., Jr. and Hare, P. E., 1972. Amino acid composition of the test as a taxonomic character for living and fossil planktonic foraminifera. Micropaleont., v. 18, p. 285-293.

Krauskopf, K. B., 1957. Separation of manganese from iron in sedimentary processes. Geochim. Cosmochim. Acta, v. 12, p. 61-84.

LaBrecque, J. L., Kent, D. V., and Cande, S. C., 1977. Revised magnetic polarity time scale for Late Cretaceous and Cenozoic time. Geology, v. 5, p. 330-335.

Le Pichon, X., Francheteau, J., and Bonnin, J., 1973. Plate Tectonics: Amsterdam (Elsevier).

Lipps, J. H., 1966. Wall structure, systematics, and phylogeny studies of Cenozoic planktonic foraminifera. J. Paleont., v. 40 , p. $1257-1273$.

1970. Plankton evolution. Evol., v. 24, p. 1-22.

Miller, R. L. and Kahn, J. S., 1962. Statistical Analysis in the Geological Sciences: New York (John Wiley).

Natland, J. H., Rosendahl, B. R., Hekinian, R., Dmitriev, Y., Fodor, R. V., Goll, R. M., Hoffert, M., Humphris, S. E., Mattey, D. P., Petersen, N., Roggenthen, W., Schrader, E. L., Srivastava, R., and Warren, N., 1979. Galapágos hydrothermal mounds: stratigraphy and chemistry revealed by deep-sea drilling. Science, v. 204, p. 613-616.

Orr, W. N. and Jenkins, D. G., 1977. Cainozoic planktonic foraminiferal zonation and selected test solution. In Ramsay, A. T. S. (Ed.), Oceanic Micropalaeontology 1: London (Academic Press), p. 163-196.

Parker, F. L., 1967. Late Tertiary biostratigraphy (planktonic foraminifera) of tropical Indo-Pacific deep-sea cores. Bull. Am. Paleont., v. 52, p. 115-208.

Parker, F. L. and Berger, W. H., 1971. Faunal and solution patterns of planktonic foraminifera in surface sediments of the South Pacific. Deep-Sea Res., v. 18, p. 73-107.

Quilty, P. G., 1976. Planktonic foraminifera DSDP Leg 34Nazca Plate. In Yeats, R. S., Hart, S. R., et al., Initial Reports of the Deep Sea Drilling Project, v. 34: Washington (U. S. Government Printing Office), p. 629-703. 
Reid, J. L., Jr., 1966. Pacific Ocean: physical oceanography. In Fairbridge, R. W. (Ed.) The Encyclopedia of Oceanography: New York (Rheinhold), p. 660-665.

Rhumbler, L., 1911. Die Foraminiferen (Thalamophoren) der Plankton-Expedition. Ergeb. Plankton-Exped. Humboldt Stiftung, v. 3, p. 1-331.

Saito, T., 1976. Geologic significance of coiling direction in the planktonic foraminifera Pulleniatina. Geology, v. 4, p. 305-309.

Saito, T., Burckle, L. H., and Hays, J. D., 1975. Late Miocene to Pleistocene biostratigraphy of equatorial Pacific sediments. Micropaleont. Spec. Publ., v. 1, p. 226-244.

Sclater, J. G., Anderson, R. N., and Bell, M. L., 1971. Elevation of ridges and evolution of the central eastern Pacific. J. Geophys. Res., v. 76, p. 7888-7915.
Sliter, W. V., 1965. Laboratory experiments on the life cycle of and ecologic control of Rosalina globularis d'Orbigny. J. Protozool., v. 12, p. 210-215.

Stainforth, R. M., Lamb, J. L., Luterbacher, H., Beard, J. H., and Jeffords, R. M., 1975. Cenozoic planktonic foraminiferal zonation and characteristics of index forms. Univ. Kansas Paleont. Contrib., v. 62, p. 1-425.

Steel, R. G. D. and Torrie, J. H., 1960. Principles and Procedures of Statistics: With Special Reference to the Biological Sciences: New York (McGraw-Hill).

Steineck, P. L. and Fleisher, R. L., 1978. Towards the classical evolutionary reclassification of Cenozoic Globigerinacea (Foraminiferida). J. Paleont., v. 52, p. 618-635.

Sverdrop, H. U., Johnson, M. W., and Fleming, R. H., 1942. The Oceans: Englewood Cliffs (Prentice-Hall).

Weyl, P. K., 1978. Micropaleontology and ocean surface climate. Science, v. 202 , p. $475-481$. 